Article

\title{
In-Bag Dry- vs. Wet-Aged Lamb: Quality, Consumer Acceptability, Oxidative Stability and In Vitro Digestibility
}

\author{
Renyu Zhang ${ }^{1,2}\left(\right.$, Michelle J. Y. Yoo ${ }^{1, *(\mathbb{D}}$, Carolina E. Realini ${ }^{2}{ }^{\oplus}$, Maryann Staincliffe ${ }^{3}$ and Mustafa M. Farouk ${ }^{2}$ \\ 1 School of Science, Faculty of Health and Environment Sciences, Auckland University of Technology, \\ Auckland 1010, New Zealand; renyu.zhang@agresearch.co.nz \\ 2 Meat Quality Team, Food \& Bio-Based Products, AgResearch Ltd., Grasslands, \\ Palmerston North 4442, New Zealand; carolina.realini@agresearch.co.nz (C.E.R.); \\ mustafa.farouk@agresearch.co.nz (M.M.F.) \\ 3 Knowledge \& Analytics, AgResearch Ltd., Ruakura Research Centre, Hamilton 3214, New Zealand; \\ maryann.staincliffe@agresearch.co.nz \\ * Correspondence: michelle.yoo@aut.ac.nz; Tel.: +64-9-921-9999 (ext. 6456)
}

check for updates

Citation: Zhang, R.; Yoo, M.J.Y.; Realini, C.E.; Staincliffe, M.; Farouk, M.M. In-Bag Dry- vs. Wet-Aged Lamb: Quality, Consumer Acceptability, Oxidative Stability and In Vitro Digestibility. Foods 2021, 10, 41. https://doi.org/ $10.3390 /$ foods 10010041

Received: 24 October 2020 Accepted: 23 December 2020 Published: 25 December 2020

Publisher's Note: MDPI stays neutral with regard to jurisdictional claims in published maps and institutional affiliations.

Copyright: (C) 2020 by the authors. Licensee MDPI, Basel, Switzerland. This article is an open access article distributed under the terms and conditions of the Creative Commons Attribution (CC BY) license (https: / / creativecommons.org/ licenses/by/4.0/).

\begin{abstract}
The aim of this study was to produce in-bag dry-aged lamb and compare its meat quality, consumer acceptability, oxidative stability and in vitro digestibility to the wet-aged equivalents. Significantly higher $\mathrm{pH}$, weight loss and reduced cook loss were observed in dry-aged lamb compared to the wet-aged $(p<0.0001)$. Dry-aged lamb had harder and chewier texture profiles and lower colour attributes $\left(\mathrm{L}^{*}, \mathrm{a}^{*}\right.$ and $\left.\mathrm{b}^{*}\right)$ than the wet-aged $(p<0.001)$. The dry-aged and wet-aged lamb were equally preferred (around $40 \%$ each) by the consumer panel, underpinning the niche nature of dry-aged meat. Significantly $(p<0.05)$ higher yeast and thiobarbituric acid reactive substances (TABRS) levels were observed in dry-aged lamb compared to the wet-aged. There was no difference in fatty acid profile, protein carbonyl content and pattern of proteolysis between ageing regimes $(p>0.05)$. Ageing regimes had no impact on overall digestibility; however, a greater gastric digestibility was observed in dry-aged lamb through the increased release of free amino acids (FAAs) compared to the wet-aged. Outcomes of this study demonstrated for the first time the possibility of producing dry-aged lamb legs of acceptable quality, oxidative stability and superior digestibility compared to the equivalent wet-aged lamb.
\end{abstract}

Keywords: in-bag dry-ageing; lamb chops; consumer acceptability; lipid oxidation; protein carbonyl; digestibility; free amino acids

\section{Introduction}

Dry-ageing is a processing technique for adding value to meat products. Dehydration, proteolysis, lipolysis and oxidation take place during dry-ageing to produce unique and intensified aged, sweet, brothy, nutty, buttery and roasted flavours compared to the widely practiced wet-aged equivalents [1,2]. Extensive studies have been carried out on various forms of dry-ageing of beef [3-5], with comparatively limited research carried out on lamb, although lamb is consumed widely around the world for its nutritional and sensorial qualities. Lamb is a good dietary source of nutrients, including iron, vitamins, high quality protein and polyunsaturated fatty acids (PUFAs), especially eicosapentaenoic acid (20:5, EPA) and docosahexaenoic acid (22:6, DHA), which are the essential omega-3 PUFAs linked to health-promoting functions [6]. Dry-aged beef is mostly produced from the middle cuts, particularly the loin, cube roll and tenderloins [4]. The equivalents of these cuts in lamb are too small to be profitably dry-aged for commercial purposes. The part of a lamb carcass that could be viably used for dry-ageing is the hindleg, known to consumers as lamb/leg chops at retail and when cooked and served in restaurants. Sheep/lamb meat consumers are familiar with wet-aged lamb chops; however, their acceptability towards the dry-aged equivalent remains unknown. 
Many factors contribute to variations in the eating quality of dry-aged meat; some of these include ageing conditions [7], level of moisture evaporation [8] and proliferation of microorganisms $[9,10]$. Pathways responsible for the development of characteristic dry-aged quality remain to be fully explored. One of the features with dry-ageing is the direct exposure of meat to oxygen in the atmosphere, which could trigger oxidative damage to lipids and proteins, producing oxidative by-products such as lipid/protein-derived carbonyls [11-13]. Oxidation has been suggested to modify the protein ultrastructure and result in protein carbonylation and aggregation [14]. Such modifications of proteins may eventually affect the solubility and functionality, leading to a decrease in proteolytic degradation and aggregation during ageing [15] and gastrointestinal digestion [16]. Interactions between oxidative changes arising from the use of different ageing regimes, proteolytic pattern and protein digestibility have not been explored.

Severe oxidative damage to lipids and proteins results in detrimental impacts on the sensorial, nutritional and functional qualities of meat $[17,18]$. To overcome these issues, dry-ageing in a moisture-permeable ageing bag, so called "in-bag dry-ageing", has been recently developed. With the use of an ageing bag as a barrier to the atmosphere, improvements in microbiological safety and product yield were also achieved when compared to the traditional out-of-bag dry-ageing [3,19]. Therefore, the aim of the present study was to produce dry-aged lamb legs using water-permeable ageing bags and to compare the dry-aged chops to their wet-aged equivalents in terms of quality, consumer acceptability, oxidative stability and in vitro digestibility.

\section{Materials and Methods}

\subsection{Sample Collection and Ageing Regimes}

Sixty lamb legs were collected from thirty carcasses (Ram, approx. 46 weeks and $26 \mathrm{~kg}$ carcass weight, $n=60$ ) at a local abattoir on the day of slaughter. Each leg (bone-in, rump muscles on, shank-off) was further portioned into three parts as shown in Figure 1. The main section, after cutting off the rump muscles and $4 \mathrm{~cm}$ from the shank side, was used for ageing. The left or right side of lamb leg (from the same animal) was randomly assigned to two ageing regimes: (1) in-bag dry-ageing using water-permeable ageing bag (TUBLIN ${ }^{\circledR}$ $10,50 \mu \mathrm{m}$ thick, polyamide mix with water vapor transmission rate $920 \mathrm{~g} / 50 \mu / \mathrm{m}^{2} / 24 \mathrm{~h}$ at $7{ }^{\circ} \mathrm{C}, 50 \% \mathrm{RH}$, and oxygen transmission rate $660 \mathrm{~g} / \mathrm{m}^{2} / 24 \mathrm{~h}$ at $7{ }^{\circ} \mathrm{C}, 50 \% \mathrm{RH}, \mathrm{TUB}-\mathrm{EX}$ ApS, Denmark) at $2 \pm 0.5^{\circ} \mathrm{C}, 0.5 \mathrm{~m} \cdot \mathrm{s}^{-1}$ air velocity and relative humidity of $75 \pm 5 \%$; (2) wetageing in water-impermeable barrier bags (Cryovac ${ }^{\circledR}$ A600 barrier bag, oxygen transmission rate $20-50 \mathrm{~g} / \mathrm{m}^{2} / 24 \mathrm{~h}$ at $23^{\circ} \mathrm{C}$, Sealed Air ${ }^{\circledR}$, Auckland, New Zealand) at $-1.5 \pm 0.5^{\circ} \mathrm{C}$ as the control. The ageing chamber comprised two compartments, as illustrated by Kim [7]: (1) an environmental test chamber (walk-in) as the main chilling chamber with control of temperature, humidity and air velocity; (2) four tunnel chambers located inside the chilling chamber with heating elements at one end and exhaust fan at the other end of the chamber to render more precise control of temperature, humidity and air velocity. Samples of both treatments were aged for 21 days. The sample weight before and after ageing was recorded to calculate the \% weight loss from 21 days of ageing. Aged samples from both treatments were fabricated into chops $(1.5 \mathrm{~cm}$ thick) with no trimming of dry surface for further quality and sensory analyses. The lamb chop for chemical analysis was minced and subsamples were taken from the same chop. 


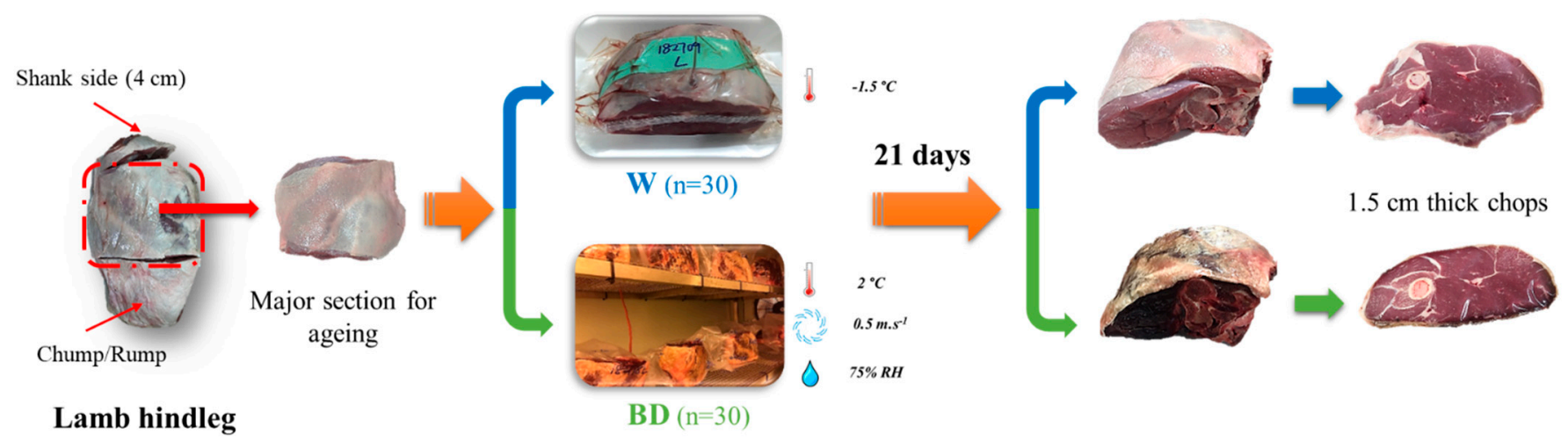

Figure 1. A schematic diagram outlining the ageing process and chops to produce in-bag dry-aged (BD) and wet-aged (W) lamb chops.

\subsection{Weight Loss, $p H$ and Proximate Content \\ 2.2.1. Ageing Weight Loss (\%)}

Sample weight was recorded at an interval of three days to calculate \% weight loss from ageing: \% Ageing weight loss $=($ (Initial weight of sample before ageing - Weight at a given time point)/Initial weight before ageing) $\times 100$. A correlation study between the initial sample weight and the weight after 21 days of ageing was also carried out to estimate the yield of dry-aged lamb under the current processing conditions based on the initial weight.

\subsubsection{Cook Loss and Percentage Total Loss (\%)}

Dry- and wet-aged lamb chops were vacuum packaged and cooked sous vide in vacuum barrier bags at $72{ }^{\circ} \mathrm{C}$ for $1 \mathrm{~h}$, then cooled in an ice bath for $1 \mathrm{~h}$ before they were transferred to $0{ }^{\circ} \mathrm{C}$ chiller overnight. The sample weight before and after cooking were recorded to calculate the percentage of cook loss. The percentage of total loss was calculated by combining the percentage of ageing loss and the percentage of cook loss.

\subsection{3. $\mathrm{pH}$}

$\mathrm{pH}$ values of lamb samples before and after the ageing treatments were measured by inserting a calibrated $\mathrm{pH}$ probe (Hanna 99,163 $\mathrm{pH}$ meter with a FC232D combined temperature and $\mathrm{pH}$ insertion probe, Woonsocket, RI, USA) directly into the meat. The calibration of $\mathrm{pH}$ meter was carried out with 2-point standard buffer solution of 7.01 and 4.01 at ambient temperature. Measurement was carried out in duplicate for each sample.

\subsubsection{Proximate Content}

The lamb chop for proximate analysis was minced and subsamples were taken from the same chop $(n=60)$. Moisture and crude fat content were determined using standard methods of AOAC 950.46 and AOAC 960.39, respectively [20]. The total muscle proteins were extracted following the method described by Zhang [5] using total muscle extraction buffer (50 mM Tris-HCl, pH 5.8; 10\% glycerol; 2\% SDS and 2\% 2-mercaptoethanol). The concentration of protein solution was determined using RC-DC protein assay kit (Bio-Rad ${ }^{\circledR}$ Laboratories, Hercules, CA, USA).

\subsection{Surface Microorganism Enumeration}

Approximately $10 \mathrm{~g}$ of samples were excised from untrimmed meat surface $(2 \mathrm{~mm}$ thick) post-ageing, using a boner's knife sanitised in 70\% alcohol. Samples were collected in sterile Whirlpak bags (Nasco, Madison, WI, USA), and transported on ice to the laboratory. Meat samples were placed into a stomacher bag and homogenised with $100 \mathrm{~mL}$ maximum recovery diluent (MRD, Difco, Detroit, MI, USA), with subsequent serial dilutions. Enumeration of microorganisms growing on the untrimmed surface of dry-aged 
lamb was determined using standard methods as described in the Compendium of Methods of Microbiological Examination of Foods [21] for Escherichia coli (E. coli, Chapter 8.91, equivalent to ISO 7251:2005) using the multiple tube technique in Lauryl Tryptose broth for $24 \mathrm{~h}$ at $44^{\circ} \mathrm{C}$; aerobic plate count (Chapter 7.62, equivalent to ISO 4883-2:2013) using standard Plate Count Agar incubated for $72 \mathrm{~h}$ at $35^{\circ} \mathrm{C}$; lactic acid bacteria (Chapter 19.522, equivalent to ISO 15214:2000) using de Man, Rogosa and Sharpe agar incubated for $72 \mathrm{~h}$ at $30{ }^{\circ} \mathrm{C}$; Enterobacteriaceae (Chapter 8.63, equivalent to ISO 21528-2:2004) using Violet Red Bile Glucose agar for $24 \mathrm{~h}$ at $37^{\circ} \mathrm{C}$; mould and yeast (Chapter 20.51, equivalent to ISO 21527-1:2008) using Dichloran Rose-Bengal Chloramphenicol Agar for 5 days at $25^{\circ} \mathrm{C}$. Results for $E$ coli were expressed as log most probable number (MPN)/g meat, and results for other microbial analysis were expressed as log colony-forming unit (cfu)/g meat.

\subsection{Instrumental Colour}

Freshly cut lamb chops from dry- or wet-ageing were placed in a polypropylene foam tray with absorbent meat pad and overwrapped with polyvinyl chloride film and allowed to bloom at $4{ }^{\circ} \mathrm{C}$ for $1 \mathrm{~h}$. Instrumental colour was measured on the surface of four major muscles, $m$. semimembranosus (SM), $m$. biceps femoris (BF), $m$. vastus lateralis (VL) and m. rectus femoris (RF), using a calibrated Minolta Chroma Meter (CR-400; Konica Minolta Photo Imaging Inc., Mahwah, NJ, USA). Three random positions were measured on each muscle. The colour coordinates of CIE L (lightness), $\mathrm{a}^{*}$ (redness) and $\mathrm{b}^{*}$ (yellowness) were measured using Illuminant D65 with $8 \mathrm{~mm}$ diameter aperture. Chroma and hue angle were further calculated to describe the colour properties of the samples according to Zhang [22].

\subsection{Instrumental Texture Profile Analysis}

Texture profile analysis was performed on four major muscles (SM, BF, VL and RF) of the cooked lamb chops from Section 2.2.2. Compression test was carried out using Stable Micro System TA.HD Plus texture analyser (Surry, UK) with a maximum loading force of $50 \mathrm{~kg}$. Each muscle was cut into $1 \mathrm{~cm}^{3}$ cubes (minimum 6 cubes per muscle) and measured against the grain using a $50 \mathrm{~mm}$ cylinder probe. The compression test was performed at $50 \%$ strain with the test speed of $5.0 \mathrm{~mm} \cdot \mathrm{s}^{-1}$ and trigger force of $5 \mathrm{~g}$. At least 6 measurements were taken for each muscle.

\subsection{Consumer Sensory Evaluation}

Lamb chops were sous vide cooked in vacuum barrier bags at $65^{\circ} \mathrm{C}$ for $75 \mathrm{~min}$ and then grilled for $60 \mathrm{~s}$ each side at approx. $180^{\circ} \mathrm{C}$ to obtain a core temperature of $72{ }^{\circ} \mathrm{C}$. The samples were then cut across the muscles to obtain two slices per chop. Each consumer was served with two slices of lamb, both slices were from the same carcass but different ageing regimes. The lamb slices were placed on a plate which was coded with two randomly selected IDs for dry- or wet-aged lamb. Consumers were informed that the two samples were from different ageing regimes and served in a random order. A group of 114 highincome ( $\geq$ NZD 70,000/year) consumers who could afford dry-aged products participated in the consumer sensory evaluation (one session). Panellists were asked to rate the degree of liking using a 9-point hedonic scale $(1=$ dislike extremely to $9=$ like extremely) and rate the eating quality using a 5-point hedonic scale $(1=$ unsatisfactory as an everyday product, $2=$ good everyday product, $3=$ slightly better than an everyday product, $4=$ almost a premium product and $5=$ a premium product). The procedures used for consumer sensory evaluation in this study have been approved by the Auckland University of Technology Ethics Committee.

A focus group is recommended to generate perceptions and/or hypotheses for an area when previous knowledge about the area is limited [23,24]. A six-member focus group was organised as a complementary study to explore the sensory descriptors of in-bag dry-aged lamb. A group of 12 persons was selected from the consumer sensory panel who participated in the acceptability evaluation of dry-aged lamb, and then they were subjected to further screening. They were screened according to the following criteria: (1) high 
income; (2) age range of 25 to 70 years; (3) high level of education (degree or higher), (4) confident to verbally express their opinions (from the 12, we selected 6 that voiced a strong positive or negative opinion on the product). The focus group discussion followed a semi-structured interview protocol according to Rabiee [25], which is summarised in Table 1.

Table 1. Interview guide for the focus group of in-bag dry-aged lamb chops.

(1) Introduction

Welcome and introduce participants.

Explain research objectives and samples information.

Explain the focus group procedure.

(2) Consent of Voluntary Participation

Inform about recording equipment and how confidentiality will be protected. Obtain verbal consent from each of the participants.

\section{(3) Cooking and Eating}

All the participants will be encouraged to observe the meat being cooked and note the aroma and general appearance of lamb chops.

Lamb presented on a table with other food accompaniments.

Participants invited to serve themselves one or more lamb chops.

\section{(4) Discussion on Why Like or Dislike Dry-Aged Lamb}

Do you like or dislike the lamb chops?

Why do you like or dislike the lamb chops?

What do you like/dislike about the cooking process and aroma?

What do you like/dislike about the aroma?

What do you like/dislike about the appearance of cooked lamb chops?

What do you like/dislike about the texture while eating?

What do you like/dislike about taste?

Do you like or dislike the flavour?

Do you think this product has a strong sheep meat (mutton) flavour?

What else do you like/dislike about the flavour?

The focus group was directed by three people, which comprised one moderator and two assistants. The moderator facilitated the discussion and the assistants took notes. The session lasted approximately $60 \mathrm{~min}$, and the discussion was recoded on an audio recorder. All the participants were seated together in a relaxed environment at home to mimic the type of environment where the product is likely to be consumed. The lamb was cooked (the same cooking method as the consumer study) in the kitchen and then presented on a table with other food accompaniments (e.g., sauces, breads and vegetables). The participants were invited to serve themselves as much lamb and other items that they wanted. They were able to serve themselves more lamb at any time during the session. Participants were informed that there were no right or wrong answers to the questions and that we were interested in gaining a better understanding of their perceptions of the product. They were encouraged to freely express their attitudes regarding the product.

\subsection{Protein Carbonyl Content}

Whole muscle protein of lamb samples was extracted using the method as described in Section 2.2.4. Concentrations of protein carbonyl groups generated from protein oxidation were measured using the 2,4-dinitrophenylhydrazine (DNPH) method proposed by Levine [26]. The extracted total muscle proteins were used and the protein extraction buffer served as a blank to react with DNPH. Absorbance of carbonyl solution was read at $370 \mathrm{~nm}$ using a UV-spectrophotometer after suspending in $6 \mathrm{M}$ guanidine $\mathrm{HCl}$ (in $20 \mathrm{mM}$ sodium phosphate buffer, $\mathrm{pH}=2.3$ ) against the blank. The measurement was performed in duplicate. 


\subsection{Lipid Oxidation and Fatty Acid (FA) Profile}

Extent of lipid oxidation was determined based on the content of thiobarbituric acid reactive substances (TBARS) according to Buege [27]. FA profile was determined according to Zhang [22].

\subsection{In Vitro Digestion of Lamb Chops}

In vitro digestion of dry- and wet-aged lamb chops was performed using a static enzymatic digestion method modified from Zhang [22]. A two-stage digestion of $240 \mathrm{~min}$ (120 min of gastric digestion and $120 \mathrm{~min}$ of intestinal/pancreatic digestion) was simulated in a bioreactor in a shaking water bath (Thermo Haake DC 10, Karlsruhe, Germany) set at $37 \pm 0.2{ }^{\circ} \mathrm{C}$ and $80 \mathrm{rpm}$. Simulated solutions of Gastric Fluid (SGF, pH = 3) and Intestinal Fluid (SIF, pH = 7) were prepared with pepsin (P6887, Sigma, Auckland, New Zealand) and pancreatin (ACROS Organics ${ }^{\mathrm{TM}}$, Thermo Fisher Scientific), respectively. Lamb chops were minced and approximately $4 \mathrm{~g}$ (with same protein content) of sub-sample was homogenised with $5 \mathrm{~mL}$ of simulated salivary fluid $(\mathrm{pH}=7)$ at 22,000 rpm (IKA Labortechnik, Germany) for $20 \mathrm{~s}$, twice to simulate mastication. Pepsin solution was added to the bioreactor to initiate gastric proteolysis (enzyme to substrate ratio of 1:278, $\mathrm{pH}=2$ ) [28]. At 0, 2, 10, 60 and $120 \mathrm{~min}$ of gastric digestion, two aliquots of $250 \mu \mathrm{L}$ hydrolysates were removed and immediately mixed with either methanol $(1: 2, v / v)$ for free amino acid (FAA) analysis or SDS-PAGE sample loading buffer $(1: 1, v / v, 50 \mathrm{mM}$ Tris-HCl, $\mathrm{pH} 6.8 ; 10 \%$ glycerol; $2 \%$ SDS; $5 \%$ 2-mercaptoethanol and $0.02 \%$ bromophenol blue) for SDS-PAGE gel electrophoresis. Aliquots for gel electrophoresis were heated at $95^{\circ} \mathrm{C}$ for $5 \mathrm{~min}$ and then stored at $-80{ }^{\circ} \mathrm{C}$ until further analysis. Pancreatin solution of enzyme to substrate ratio of 1:100 was added to initiate the intestinal digestion at $\mathrm{pH} 7$ for $120 \mathrm{~min}$. Aliquots of hydrolysates were removed from the reactor and treated the same as those collected in the gastric phase.

\subsubsection{SDS-PAGE Gel Electrophoresis}

Hydrolysates collected from the digestion simulation were loaded onto $\mathrm{Novex}^{\mathrm{TM}} \mathrm{Nu}-$ PAGE ${ }^{\mathrm{TM}} 10 \%$ Bis-Tris Midi Protein Gels (Invitrogen ${ }^{\mathrm{TM}}$, Thermo Fisher Scientific, Auckland, New Zealand) by $40 \mu \mathrm{g}$ proteins per well and separated at ambient temperature in a Bio-Rad Criterion cell system at $150 \mathrm{~V}$ using PowerPac ${ }^{\mathrm{TM}} \mathrm{HC}$ High-Current Power Supply (Bio-Rad ${ }^{\circledR}$ Laboratories, Hercules, CA, USA). An 8- $\mu$ l aliquot of Novex ${ }^{\mathrm{TM}}$ Sharp Pre-stained protein standard (Invitrogen, UK) was used to determine molecular weight (MW) of different protein sizes from 3.5 to $260 \mathrm{kDa}$. Following electrophoresis, gels were stained in a SimplyBlue SafeStain (Invitrogen ${ }^{\mathrm{TM}}$ ) for $4 \mathrm{~h}$. Stained gels were then washed with distilled water and images were captured with a GS900 calibrated densitometer scanner (Bio-Rad ${ }^{\circledR}$ Laboratories). The gels were loaded following the order which enabled the time-course of digestion $(0,2,10,60,120$ and $240 \mathrm{~min})$ to be visualised and for dry- and wet-ageing treatments to be compared.

\subsubsection{Analysis of Free Amino Acids (FAAs)}

Aliquots for FAA profile were centrifuged at $10,000 \times g$ for $10 \mathrm{~min}$. The supernatant containing FAA extract was quantified by Agilent 1260 Infinity HPLC system equipped with Agilent 6420 Triple Quadrupole LC/MS system (Agilent Technologies New Zealand Limited, Wellington, New Zealand), according to Zhang [29]. The AA standard solution $(100 \mu \mathrm{M})$ of 40 amines (included internal standard) prepared with the 37 AA standard mixture (A9906, Sigma, Auckland, New Zealand), asparagine (A0884, Sigma, Auckland, New Zealand) and glutamine (G3126, Sigma, Auckland, New Zealand) was serially diluted to $0.78 \mu \mathrm{M}$ to generate a standard curve for the identification and quantification of FAAs using MassHunter software (Agilent Technologies). The final concentration of FAAs was expressed as $\mathrm{mg} / \mathrm{g}$ protein. 


\subsubsection{Relative Protein Digestibility (\%)}

The relative protein digestibility following $240 \mathrm{~min}$ of simulated gastrointestinal digestion was determined by three methods: (1) the protein profile using SDS-PAGE electrophoresis (Section 2.9.1), (2) the release of FAAs (Section 2.9.2) and (3) the protein content (protein fragments and peptides) in the hydrolysates after pancreatic digestion using RC-DC protein assay kit (Bio-Rad ${ }^{\circledR}$ Laboratories, Hercules, CA, USA). Relative digestibility (\%) was calculated as follows:

(1) Relative digestibility SDS-PAGE $=(1-$ (Optical intensity of protein bands $<10 \mathrm{kDa} /$ Optical intensity of all protein bands) $) \times 100$

(2) Relative digestibility FAAs $=(($ Total FAAs (g) at $240 \mathrm{~min}-$ total FAAs (g) at $0 \mathrm{~min}) /$ Protein content of the sample) $\times 100$

(3) Relative digestibility Protein content $=(1-$ Protein content (g) in hydrolysate at $240 \mathrm{~min} /$ Protein content of the sample) $\times 100$

\subsection{Statistical Analysis}

A randomised control trial was designed with thirty pairs of lamb legs $(n=60)$ which were evenly assigned to two different treatments: in-bag dry-ageing and wet-ageing. A model including the fixed effect of ageing treatments and the random effect of carcass ID and carcass sides was used for chemical analysis of minced chops. For instrumental colour and texture profile analysis, the ageing treatments and muscles were considered as fixed effects, and carcass ID and carcass sides were considered as random effects fitted in the model. For the sensory evaluation analysis, the ageing treatments were included as the fixed effects; panellists, carcass ID and muscles of lamb chops were included as the random effect in this model. Linear mixed effect regression analyses were performed on the data using R (version 3.4.1), with "lme4" and "predictmeans" packages to determine the difference between ageing treatments. Analysis of variance (ANOVA, one-way) was used to investigate the effect of different ageing treatments with a post-hoc comparison of means performed using Fisher's least significant differences (LSD) and Tukey's (HSD) test at $5 \%$ significance level. A power curve was generated to describe the relationship between $\%$ ageing weight loss and ageing time under the current dry-ageing process. The Chi-squared test was performed on the eating quality rating of two ageing methods at $5 \%$ significance level.

\section{Results and Discussion}

\subsection{Meat Quality}

\subsubsection{Weight Losses}

The weight losses during ageing and cooking were measured to estimate the yield of dry-aged lamb chops from processing to the point of consumption. In-bag dry-ageing resulted in a significantly $(p<0.0001)$ higher weight loss than wet-ageing, which was expected in dry-aged meat products. The change in weight loss from dry-ageing over time is shown in Figure 2a. In general, around $20 \%$ of moisture was lost from dry-aged lamb after 21 days of ageing time as compared to the control with an average of $0.71 \%$ purge loss. The relationship $\left(R^{2}=0.9983\right)$ between \% weight loss from ageing and ageing time under the current dry-ageing process is shown as follows:

$$
Y=0.0552 X^{0.6783} \times 100
$$

$\mathrm{Y}=\%$ weight loss from ageing;

$\mathrm{X}=$ Days of ageing

The correlation between the initial weight (applicable range: $0.5-2 \mathrm{~kg}$ ) and dry-aged weight (21 days) was calculated to predict the yield of dry-aged lamb when the initial weight was known (Figure $2 b)$. A close to linear relationship $\left(R^{2}=0.9844\right)$ was found as follows:

$$
Y=0.9044 X-151
$$


$\mathrm{Y}=$ Dry-aged weight $(\mathrm{g})$ at 21 days of ageing;

$\mathrm{X}=$ Initial weight $(\mathrm{g})$ before ageing

Cook loss of dry-aged lamb was significantly reduced to an average value of $16.94 \%$ compared to the control (27.79\%, Table 2). Similar findings were reported on beef products where cook loss was lower in the dry-aged beef than wet-aged counterparts $[19,30,31]$. Although the total loss (ageing weight loss + cook loss) remained significantly higher in dry-aged samples (36.52\%) than the control $(28.48 \%)$, the difference between the two ageing treatments was reduced to less than $10 \%$.

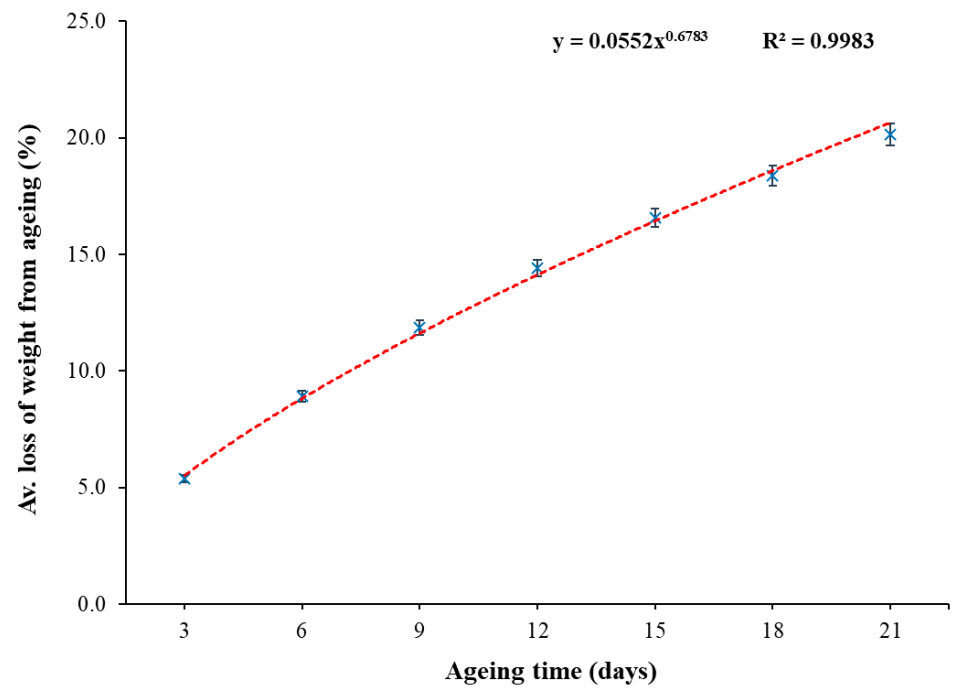

(a)

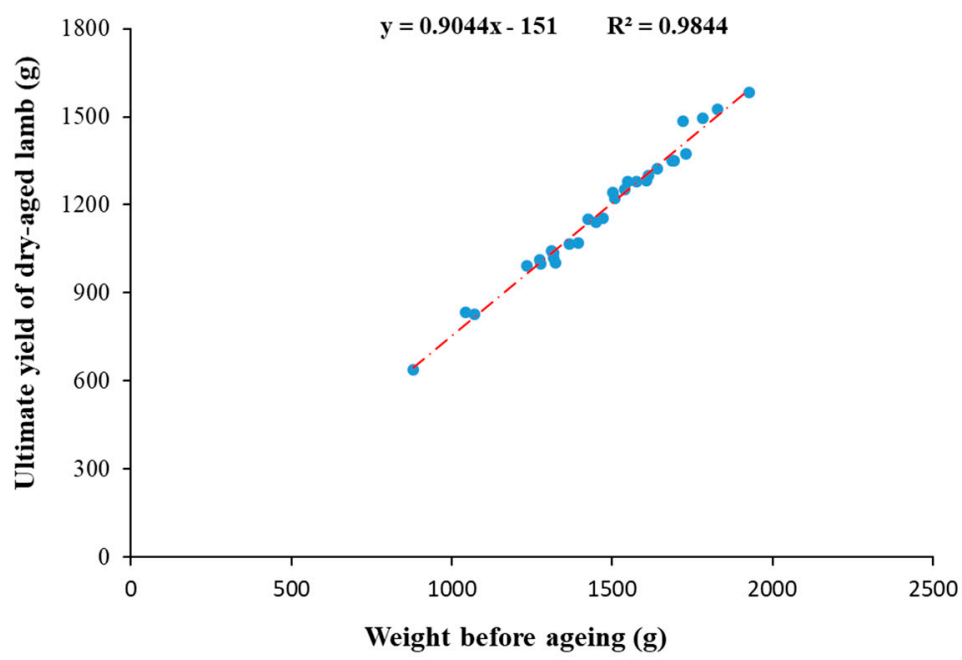

(b)

Figure 2. (a) Average loss of weight from ageing (\%) observed in in-bag dry-aged lamb across 21 days of ageing time. A trendline was added to establish the power relationship between the weight loss from ageing with ageing time. Error bars represent standard errors $(n=30)$. (b) Initial weight (g) of lamb legs before ageing and the ultimate yield $(\mathrm{g})$ of in-bag dry-aged lamb $(n=30)$. A trendline was added to predict the linear relationship between the weight of lamb samples before and post in-bag dry-ageing. 
Table 2. Effect of ageing treatments on the physico-chemical and microbial properties of lamb chops.

\begin{tabular}{|c|c|c|c|c|}
\hline & $\mathbf{W}^{1}$ & BD $^{1}$ & SED $^{2}$ & $p$-Ageing \\
\hline $\mathrm{pH}$ & $5.92^{\mathrm{a}}$ & $6.04^{b}$ & 0.02 & $<0.0001$ \\
\hline$\%$ Moisture & $73.25^{a}$ & $67.30^{b}$ & 0.37 & $<0.0001$ \\
\hline$\%$ Crude fat & 5.93 & 6.82 & 0.46 & 0.058 \\
\hline$\%$ Muscle protein & $16.54^{\mathrm{a}}$ & $20.22^{b}$ & 0.24 & $<0.0001$ \\
\hline$\%$ Cook loss & $27.79^{a}$ & $16.94^{b}$ & 0.67 & $<0.0001$ \\
\hline$\%$ Total loss & $28.48^{\mathrm{a}}$ & $36.52^{b}$ & 0.56 & $<0.0001$ \\
\hline \multicolumn{5}{|c|}{ Meat Surface Microbial Count (Mean log cfu/g) } \\
\hline Aerobic bacteria & $5.16^{\mathrm{a}}$ & $2.68^{b}$ & 0.75 & 0.030 \\
\hline Lactic acid bacteria & 2.64 & n.d. & - & - \\
\hline Moulds & n.d. ${ }^{3}$ & n.d. & - & - \\
\hline Yeast & $2.38^{a}$ & $3.75^{b}$ & 0.47 & 0.043 \\
\hline Enterobacteriaceae & 2.36 & n.d. & - & - \\
\hline Escherichia coli (log MPN/g) & n.d. & n.d. & - & - \\
\hline
\end{tabular}

\footnotetext{
${ }^{1} \mathrm{~W}$ and BD refer to wet-aged and in-bag dry-aged, respectively; ${ }^{2}$ SED is the standard error of a difference between means; ${ }^{3}$ n.d. refers to not detectable (under detection limit, $<1.00 \log \mathrm{cfu} / \mathrm{g}$ for moulds and Enterobacteriaceae, and $<0.48 \log$ MPN/g for Escherichia coli); Different superscript letters " $a, b$ " within the same row indicate that results significantly differed from each other $(p<0.05)$.
}

\subsubsection{Proximate Content and $\mathrm{pH}$}

The moisture content of dry-aged lamb $(67.30 \%)$ was significantly $(p<0.05)$ lower than the wet-aged counterparts $(73.25 \%)$, which contradicts the outcomes of other studies that found no difference in moisture content between wet- and dry-ageing treatments $[3,30]$. This could be attributed to dehydration as part of the dry-ageing process mainly occurring on the outer surface of the meat. Most studies have trimmed the surface crust of dryaged meat prior to sampling for moisture content analysis, thus eliminating the difference that would have been observed [5]. With the use of dry-ageing bags, no trimming was necessary in this study. Lower moisture levels in dry-aged lamb were expected owing to the significantly higher weight loss in the in-bag dry-aged sample compared to wet-aged after 21 days of ageing.

Dry-aged lamb had higher $(p=0.058)$ crude fat $(6.82 \%)$ and protein $(20.22 \%)$ contents compared to the wet-aged control (5.93\% fat and $16.54 \%$ protein), which agreed with the outcomes of other studies on beef [30,31]. The increase in fat and protein content in the current study may be attributed to the significant decrease in moisture content, which concentrated the other components of lamb.

Both ageing methods significantly $(p<0.05)$ increased the $\mathrm{pH}$ values of lamb from the average value of 5.83 (before ageing) to 5.92 (wet-aged) and 6.04 (dry-aged), respectively (Table 2). The increase in $\mathrm{pH}$ after ageing has been well reported on beef [5,32,33], which could be associated with the production of nitrogenous compounds by proteolysis. (In-bag) dry-ageing has been reported to increase the $\mathrm{pH}$ of beef loins [19] with ageing time and for the dry-aged samples to have a higher $\mathrm{pH}$ value than the wet-aged counterparts [1].

\subsubsection{Surface Microorganism Growth}

Overall, the surface microorganism counts were low in both dry- and wet-aged lamb (Table 2). A significantly $(p<0.05)$ higher level of yeast was found in dry-aged lamb with the lower aerobic bacterial counts compared to the wet-aged. It is speculated that the low moisture environment on the surface of dry-aged meat favoured the proliferation of yeast, which consumed the available oxygen on the meat's surface and consequently outcompeted the aerobic bacteria. There remains a need for future study to confirm the current hypothesis. A higher yeast level was also observed in dry-aged beef than the wet-aged counterparts $[1,5,19]$. There were no $E$. coli and moulds detected in both treatments, which was also observed in a previous study on beef [34]. Lactic acid bacteria and Enterobacteriaceae counts were found higher on the surface of wet-aged lamb samples than the dry-aged. Similar findings of lactic acid bacteria were also reported by Li [19] 
between wet- and dry-aged beef, which could be attributed to the anaerobic environment of wet-ageing favouring the proliferation of lactic acid bacteria. Contradictory results have been reported on the Enterobacteriaceae counts of dry-aged beef being higher [1] or similar [19] compared to the wet-aged control.

\subsubsection{Instrumental Colour}

The ageing process affected the colour properties of lamb. All the colour attributes were lower $(p<0.05)$ in dry-aged lamb than the wet-aged except for hue angle and VL a* $(p>0.05)$ (Table 3). Overall, in-bag dry-ageing generated a slightly darker, less red and less yellow colour, which could be associated with the moisture loss during the ageing process. The dehydration of dry-aged lamb reduced the light reflection and concentrated colour components including myoglobin and iron that result in changes in the meat colour. Similar effects of dry-ageing on beef colour were reported by Kim [7]. Colour plays an essential role in consumer acceptability of lamb. The minimum thresholds for $\mathrm{L}^{*}$ and $\mathrm{a}^{*}$ for consumer colour acceptability have been reported as 34 to 35 and 9.5, respectively [35]. The colour of the lamb samples from both ageing treatments were within the acceptable colour range; thus, in-bag dry-ageing had no negative effect on the colour quality of lamb after 21 days of ageing.

Table 3. Effect of ageing treatments and muscle types on instrumental colour of lamb chops.

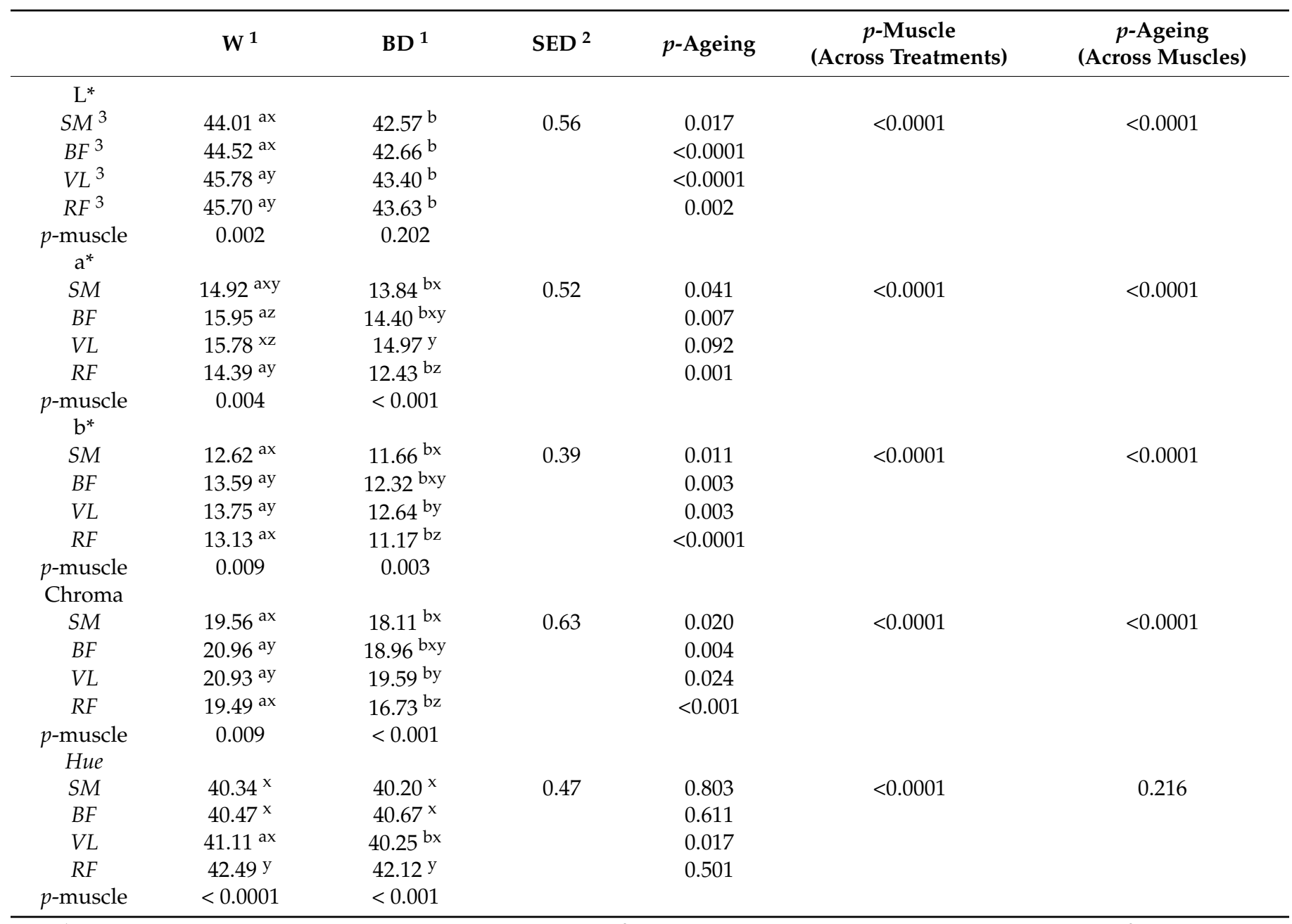

${ }^{1} \mathrm{~W}$ and BD refer to wet-aged and in-bag dry-aged, respectively; ${ }^{2}$ SED is the standard error of a difference between means; ${ }^{3} S M, B F, V L$ and $R F$ refer to $m$. semimembranosus, $m$. biceps femoris, $m$. vastus lateralis and $m$. rectus femoris, respectively; Different superscript letters "a, $\mathrm{b}$ " within the same row indicate that results significantly differed from each other $(p<0.05)$; Different superscript letters " $x, y$, $z$ " within the same column indicate that results significantly differed from each other $(p<0.05)$. 
There was no difference in the way in which the ageing treatments affected the colour of the four muscles of lamb chops, though an exception was seen for the VL muscle of dry-aged lamb, which was less brown (lower hue) than the wet-aged control $(p<0.05$, Table 3). The impact of different muscles on the colour properties in the current study may be associated with the inherent variations across muscles, including $\mathrm{pH}$, the content of fat, iron and myoglobin [36] and also the oxidative stability of myoglobin [37].

\subsubsection{Instrumental Texture Profile Analysis}

Most of the study on dry-aged beef products focused on the tenderness of the meat as compared to the wet-aged. However, the texture profile of dry-aged products has not been well explored, particularly for dry-aged lamb. The majority of studies on beef failed to detect any significant difference in shear force between dry- and wet-aged beef $[7,19,31,38]$, suggesting that improvement in tenderness was not an advantage of dry-aged products over wet-aged, considering that both ageing methods can effectively tenderise the meat to similar levels.

As shown in Table 4, both ageing treatments produced lamb samples which were tender and easy to chew (low force values for hardness and chewiness). Significantly $(p<0.05)$ higher hardness and chewiness were detected in dry-aged lamb compared to wet-aged, likely as a result of dehydration of the samples, which caused shrinkage and resulted in a firm texture. Cohesiveness and resilience of dry-aged lamb were slightly $(p<0.05)$ lower as compared to the wet-aged control. However, the difference between the two treatments was numerically too small to have a significant impact on the textural properties of the meat.

Table 4. Effect of ageing treatments and muscle types on the texture profile analysis of the lamb chops.

\begin{tabular}{|c|c|c|c|c|c|c|}
\hline & $W^{1}$ & $\mathrm{BD}^{1}$ & SED $^{2}$ & $p$-Ageing & $\begin{array}{c}p \text {-Muscle } \\
\text { (Across Treatments) }\end{array}$ & $\begin{array}{c}p \text {-Ageing } \\
\text { (Across Muscles) }\end{array}$ \\
\hline \multicolumn{7}{|l|}{$\begin{array}{l}\text { Hardness } \\
(\mathrm{N})\end{array}$} \\
\hline$S M^{3}$ & $21.14^{\mathrm{a}}$ & $25.27^{b}$ & 1.66 & 0.015 & 0.366 & $<0.001$ \\
\hline$B F^{3}$ & 22.53 & 26.50 & & 0.067 & & \\
\hline$V L^{3}$ & $22.48^{a}$ & $27.19^{b}$ & & 0.004 & & \\
\hline$R F^{3}$ & 22.17 & 24.45 & & 0.120 & & \\
\hline$p$-muscle & 0.680 & 0.465 & & & & \\
\hline \multicolumn{7}{|l|}{$\begin{array}{l}\text { Chewiness } \\
(\mathrm{N})\end{array}$} \\
\hline$S M$ & 7.47 & 8.46 & 0.69 & 0.134 & 0.017 & $<0.001$ \\
\hline$B F$ & $8.22^{a}$ & $9.89^{b}$ & & 0.048 & & \\
\hline$V L$ & $7.67^{\mathrm{a}}$ & $9.46^{b}$ & & 0.014 & & \\
\hline$R F$ & 7.27 & 7.87 & & 0.309 & & \\
\hline$p$-muscle & 0.414 & 0.051 & & & & \\
\hline \multicolumn{7}{|l|}{ Springiness } \\
\hline$S M$ & $0.62^{x y}$ & $0.63^{x}$ & 0.02 & 0.514 & $<0.0001$ & 0.427 \\
\hline$B F$ & $0.65^{x}$ & $0.65^{x}$ & & 0.979 & & \\
\hline$V L$ & $0.61^{\mathrm{y}}$ & $0.62 x y$ & & 0.463 & & \\
\hline$R F$ & $0.59 \mathrm{y}$ & $0.60 \mathrm{y}$ & & 0.657 & & \\
\hline$p$-muscle & 0.012 & 0.010 & & & & \\
\hline \multicolumn{7}{|c|}{ Cohesiveness } \\
\hline$S M$ & $0.56^{\mathrm{a}}$ & $0.53^{b}$ & 0.01 & 0.002 & 0.597 & 0.001 \\
\hline$B F$ & 0.55 & 0.54 & & 0.360 & & \\
\hline$V L$ & 0.55 & 0.54 & & 0.497 & & \\
\hline$R F$ & 0.55 & 0.53 & & 0.057 & & \\
\hline$p$-muscle & 0.373 & 0.354 & & & & \\
\hline
\end{tabular}


Table 4. Cont.

\begin{tabular}{|c|c|c|c|c|c|c|}
\hline & $W^{1}$ & BD $^{1}$ & SED $^{2}$ & $p$-Ageing & $\begin{array}{c}p \text {-Muscle } \\
\text { (Across Treatments) }\end{array}$ & $\begin{array}{c}p \text {-Ageing } \\
\text { (Across Muscles) }\end{array}$ \\
\hline \multicolumn{7}{|c|}{ Adhesiveness } \\
\hline$S M$ & -11.56 & -18.13 & 4.10 & 0.229 & 0.054 & 0.335 \\
\hline$B F$ & -9.18 & -8.35 & & 0.229 & & \\
\hline$V L$ & -10.93 & -12.31 & & 0.736 & & \\
\hline$R F$ & -7.08 & -8.44 & & 0.593 & & \\
\hline$p$-muscle & 0.439 & 0.127 & & & & \\
\hline \multicolumn{7}{|l|}{ Resilience } \\
\hline$S M$ & $0.23^{\mathrm{a}}$ & $0.21^{\mathrm{b}}$ & 0.01 & 0.017 & 0.284 & 0.048 \\
\hline$B F$ & 0.22 & 0.22 & & 0.845 & & \\
\hline$V L$ & 0.22 & 0.22 & & 0.465 & & \\
\hline$R F$ & 0.22 & 0.21 & & 0.356 & & \\
\hline$p$-muscle & 0.123 & 0.443 & & & & \\
\hline
\end{tabular}

${ }^{1} \mathrm{~W}$ and BD refer to wet-aged and in-bag dry-aged, respectively; ${ }^{2}$ SED is the standard error of a difference between means; ${ }^{3} S M, B F, V L$ and $R F$ refer to $m$. semimembranosus, $m$. biceps femoris, $m$. vastus lateralis and $m$. rectus femoris, respectively; Different superscript letters "a, $\mathrm{b}$ " within the same row indicate that results significantly differed from each other $(p<0.05)$. Different superscript letters " $x$, $y$," within the same column indicate that results significantly differed from each other $(p<0.05)$.

Lamb legs consist of multiple muscles. Different muscles were affected differently by the ageing treatments. As shown in Table 4 , the type of muscle only influenced the hardness, chewiness and springiness of lamb samples. A significant $(p<0.05)$ difference in hardness between ageing treatments was seen in SM and VL muscles. Dry-aged lamb was slightly chewier than the control; however, a significant $(p<0.05)$ increase was only observed in BF and VL muscles.

\subsection{Sensory Quality}

\subsubsection{Consumer Acceptability}

The palatability of in-bag dry-aged lamb has not been previously evaluated. As shown in Table 5, both lamb samples were equally preferred $(p>0.05)$ by the consumer panellists as a "better than everyday product". The average degree of preference for both samples (in-bag dry-aged $=6.68$, wet-aged $=6.75$ ) was close to "like moderately", which was score 7 .

Table 5. Effect of ageing treatments on the sensory quality of lamb chops.

\begin{tabular}{ccccc}
\hline & $\mathbf{W}^{\mathbf{1}}$ & BD $^{\mathbf{1}}$ & SED $^{\mathbf{2}}$ & $p$-Ageing \\
\hline Degree of Liking & 6.75 & 6.68 & 0.19 & 0.682 \\
\% preferred $^{3}$ & 44.74 & 40.35 & & \\
Eating Quality Rating $_{\text {\% rating }}^{4}$ & 3.14 & 3.10 & 0.13 & 0.750 \\
Unsatisfactory as an everyday product $_{\text {Good everyday product }}$ & 2.65 & 4.42 & & 0.670 \\
Slightly better than an everyday product & 29.20 & 23.89 & & \\
Almost a premium product & 31.86 & 37.17 & & \\
A premium product & 24.78 & 26.55 & & \\
\hline
\end{tabular}

\footnotetext{
${ }^{1} \mathrm{~W}$ and BD refer to wet-aged and in-bag dry-aged, respectively; ${ }^{2}$ SED is the standard error of a difference between means; ${ }^{3}$ results were calculated as \% consumers rated W or BD sample higher than its equivalent; ${ }^{4}$ results were calculated as \% consumers rated on the five-point scale eating quality groups of $\mathrm{W}$ and $\mathrm{BD}$ samples.
}

The sensory quality of in-bag dry-aged beef compared to wet-aged has been extensively studied but the results were inconsistent. For instance, in-bag dry-aged beef samples have been reported to be preferred by consumers to the wet-aged counterparts $[7,19,39]$; no difference [40,41]; or wet-aged products preferred [38]. The conflicting findings may have arisen from the use of different ageing processes, types of muscles and breeds. 
Dry-aged meat is a niche product which is expected to be only preferred by a certain group of consumers. Therefore, the debate on different ageing methods should be focused on how many (more) consumers would prefer dry-/wet-aged products instead of which products were more palatable than the other because they are all palatable. In the current study, $44.74 \%$ of consumers rated wet-aged lamb higher in terms of overall preference. This was more likely owing to their familiarity with wet-aged lamb products. It was promising to observe a similar number $(40.35 \%)$ of consumers that preferred in-bag dryaged lamb to the wet-aged counterparts (44.74\%). There was only a small group $(14.95 \%$ on overall preference) of consumers who could not distinguish between in-bag dry-aged and wet-aged lamb. In eating quality rating, there was no significant difference between the average score of in-bag dry-aged and wet-aged lamb. Both in-bag dry- and wet-aged samples were considered by most of the consumers ( $71.68 \%$ and $68.14 \%$, respectively) as slightly higher than an everyday product (score 3). Considering that these were lamb chops and not lamb loins that were assessed, this overall level of acceptability is highly promising for this lamb cut. No significant difference (chi-square; $p=0.670$ ) was found in the distribution of response along the 5-point scale consumer rating of eating quality between the two ageing methods (Table 5). Therefore, the current findings suggest a niche market for dry-aged products and a great market potential for in-bag dry-aged lamb.

\subsubsection{Focus Group Perceptions of In-Bag Dry-Aged Lamb Chops}

In the present study, a focus group was used phenomenologically to strengthen the outcomes of the quantitative survey with the targeted consumers due to the paucity of information on dry-aged lamb. Members of the focus group in the present study discussed and described the characteristics of in-bag dry-aged lamb chops based on their eating experience of lamb products. Out of the six members, only one member did not like the in-bag dry-aged lamb chop because of the drier texture, though the same person perceived the flavour of the meat as pleasant.

Appearance and aroma: The "lean (not fatty)" appearance of in-bag dry-aged lamb chops was considered as an advantage. "Dry (not juicy)" appearance was another attribute of in-bag dry-aged lamb which may be one of the key features of dry-aged products. The dehydration process of dry-ageing caused a certain level of moisture loss and resulted in a "dry look". All the focus group panellists strongly liked the (cooked meat) aroma of the in-bag dry-aged lamb and described it as "fine/pleasant aroma" and "less mutton smell (unpleasant) than the normal lamb".

Texture: All of the group members agreed that the texture of in-bag dry-aged lamb was "tender", "spongy" and "less fibrous". These attributes were considered as positive descriptors for the texture characteristics of in-bag dry-aged lamb chops. These attributes were also observed from the consumer sensory session, which found that the consumers who preferred in-bag dry-aged lamb liked the "chewier" texture rather than too soft/tender texture of the wet-aged lamb.

Taste/flavour: The taste/flavour of in-bag dry-aged lamb was considered as nutty, sweet with aftertaste, venison-like (gamey), stronger lamb flavour (pleasant) but no mutton flavour (unpleasant), no fatty taste or greasy aftertaste (even when cold). A stronger umami and sweet taste, buttery, nutty, brothy and roasted flavours were also detected previously in (in-bag) dry-aged beef samples as compared to the wet-aged counterparts [1,42]. The suggestion by the focus group that dry-aged lamb left no greasy coating is highly significant as one of the issues that consumers have with lamb meat is the coating of the mouth and throat often experienced on eating lamb due to the high melting temperatures of lamb fat $[43,44]$. This quality change as a result of dry-ageing needs to be further ascertained and, if confirmed, should be used to differentiate dry-aged lamb from its wet-aged equivalent. 


\subsection{Protein and Lipid Oxidation}

\subsubsection{Protein Carbonyl Content}

Assessment of protein carbonyl content has been widely used to estimate the extent of protein oxidation. As shown in Table 6, overall, the protein carbonyl content was low in both lamb samples $(p>0.05)$. The protein carbonyl naturally exists in the animal tissues at a level of 1-2 nmol.mg ${ }^{-1}$ and increases during rigor mortis [11,13]. It has been reported that post-mortem ageing may promote the carbonylation of meat proteins [13,29]. However, the influence was highly dependent on the source of meat, type of muscle and, particularly, the storage conditions [45]. Storage under high-oxygen atmosphere at higher temperature or exposure to the reactive agents such as light, transition metals $\left(\mathrm{Fe}^{3+} / \mathrm{Cu}^{2+}\right)$ and oxidising lipids could also trigger protein oxidation. In the current study, the barrier function of the ageing bag limited the oxygen availability in the meat [19], which reduced the potential for the carbonylation of protein and resulted in a similar carbonyl level as the control.

Table 6. Effect of ageing treatments on the oxidative changes in lipid and protein of lamb chops.

\begin{tabular}{|c|c|c|c|c|}
\hline & $W^{1}$ & $\mathrm{BD}^{1}$ & SED $^{2}$ & $p$-Ageing \\
\hline Protein Carbonyl (nmol/mg Protein) & 2.20 & 2.31 & 0.08 & 0.151 \\
\hline TBARS $^{3}\left(\mathrm{mg} \mathrm{MDA}^{3} / \mathrm{kg}\right.$ Meat$)$ & $0.38^{a}$ & $1.30^{b}$ & 0.13 & $<0.0001$ \\
\hline \multicolumn{5}{|l|}{ Fatty Acid Profile (mg/g dry Matter) } \\
\hline $10: 0$ & 0.18 & 0.17 & 0.02 & 0.631 \\
\hline $12: 0$ & 0.35 & 0.33 & 0.03 & 0.539 \\
\hline $14: 0$ & 2.56 & 2.44 & 0.22 & 0.580 \\
\hline $14: 1$ & 0.09 & 0.09 & 0.01 & 0.490 \\
\hline $15: 0$ & 0.27 & 0.25 & 0.02 & 0.390 \\
\hline $16: 0$ & 12.71 & 12.44 & 0.72 & 0.706 \\
\hline $16: 1$ & 1.00 & 1.01 & 0.07 & 0.879 \\
\hline $17: 0$ & 1.10 & 1.07 & 0.05 & 0.542 \\
\hline $17: 1$ & 0.38 & 0.37 & 0.02 & 0.490 \\
\hline $18: 0$ & 10.89 & 10.60 & 0.57 & 0.606 \\
\hline $18: 1\left(n^{3}-9\right.$, cis \& trans $)$ & 18.37 & 18.22 & 1.06 & 0.887 \\
\hline $18: 2(n-6$, cis \& trans $)$ & 2.00 & 2.02 & 0.07 & 0.715 \\
\hline $18: 3(n-6)$ & 0.21 & 0.21 & 0.02 & 0.848 \\
\hline $18: 3(n-3)$ & 1.31 & 1.29 & 0.05 & 0.713 \\
\hline 20:0 & 0.19 & 0.20 & 0.01 & 0.272 \\
\hline $20: 2(n-6)$ & 0.15 & 0.16 & 0.01 & 0.429 \\
\hline $20: 6(n-6)$ & 0.23 & 0.23 & 0.01 & 0.873 \\
\hline $20: 5(n-3)$ & 0.69 & 0.70 & 0.02 & 0.801 \\
\hline $22: 0$ & 0.27 & 0.27 & 0.01 & 0.900 \\
\hline $24: 0$ & 0.20 & 0.20 & 0.01 & 0.946 \\
\hline $22: 6(n-3)$ & 0.36 & 0.35 & 0.01 & 0.725 \\
\hline UFAs $^{3}$ & 24.80 & 24.65 & 1.24 & 0.905 \\
\hline SFAs $^{3}$ & 28.72 & 27.96 & 1.47 & 0.609 \\
\hline MUFAs $^{3}$ & 19.84 & 19.68 & 1.14 & 0.890 \\
\hline$n-3$ & 2.36 & 2.34 & 0.05 & 0.756 \\
\hline$n-6$ & 2.59 & 2.62 & 0.08 & 0.734 \\
\hline PUFAs $^{3}$ & 4.95 & 4.96 & 0.12 & 0.928 \\
\hline$\%$ UFAs & 46.40 & 46.92 & 0.47 & 0.266 \\
\hline \% SFAs & 53.60 & 53.08 & 0.47 & 0.266 \\
\hline$\%$ MUFAs & 36.87 & 37.15 & 0.54 & 0.609 \\
\hline$\% n-3$ & 4.56 & 4.64 & 0.22 & 0.721 \\
\hline$\% n-6$ & 4.96 & 5.14 & 0.20 & 0.390 \\
\hline$\%$ PUFAs & 9.52 & 9.77 & 0.40 & 0.534 \\
\hline
\end{tabular}

${ }^{1} \mathrm{~W}$ and BD refer to wet-aged and in-bag dry-aged, respectively; ${ }^{2}$ SED is the standard error of a difference between means; ${ }^{3}$ TBARS, MDA, UFAs, SFAs, MUFAs, PUFAs and $n$ refer to thiobarbituric acid reactive substances, malondiadehyde, unsaturated fatty acids, saturated fatty acids, monounsaturated fatty acids, poly-unsaturated fatty acids and omega, respectively; Different superscript letters " $\mathrm{a}, \mathrm{b}$ " within the same row indicate that results significantly differed from each other $(p<0.05)$. 


\subsubsection{TBARS and FA Profile}

Lipid is more susceptible to oxidative damage than protein during post-mortem storage [12]. TBARS has been widely used to evaluate the extent of lipid oxidation by measuring the content of lipid peroxidation products, malondiadehyde (MDA), present in the samples [46].

As shown in Table 6, a significantly higher TBARS value was detected in dry-aged lamb compared to the wet-aged. However, the TBARS level in the current study was below the rancidity threshold of $2.0 \mathrm{mg}$ MDA [47]. Jiang [48] found no significant difference in TBARS between dry- and wet-aged beef samples. In-bag dry-ageing was reported to lower lipid oxidation (lower TBARS) in beef products compared to the traditional dry-ageing [30]. As described earlier, dry-ageing is an aerobic maturation process involving a certain degree of oxidation and resulting in oxidative by-products. These oxidative products participate later in cooking and produce a range of volatiles such as aldehydes, hydrocarbons, ketones and lactones, which may contribute towards the flavour intensity of meat [49-51].

The FA content was not affected ( $p>0.05$, Table 6$)$ by the ageing treatments, suggesting that the in-bag dry-ageing did not negatively affect the nutritional value of FAs in lamb. It is worth noting that in-bag dry-ageing did not adversely affect PUFAs, including EPA and DHA. Therefore, the nutritional value of lamb was not affected by the current in-bag dry-ageing process in terms of FA profile, although an increase in TBARS level in the in-bag dry-aged lamb was observed. The increase in oxidative potential (TBARS), on the other hand, may be associated with the flavour development of dry-aged products as discussed above.

\subsection{Proteolysis}

Protein profiles (SDS-PAGE) of in-bag dry- and wet-aged lamb are shown in Figure 3 (0 min). No difference in protein profiles between the ageing regimes was observed, suggesting that a similar proteolytic pattern occurred due to the activities of endogenous proteases regardless of the ageing regimes. Similar protein profile (SDS-PAGE) was detected previously in beef muscles aged by traditional out-of-bag dry-ageing [52], in-bag dry-ageing [29] and wet-ageing regimes. Peptides of smaller than $<3 \mathrm{kDa}$ were present in higher amounts in dry-aged beef compared to the wet-aged [52]. This could be due to the proliferation of microorganisms (mould and yeast) during dry-ageing, which contributed towards the proteolytic activity of peptidases and resulted in different compositions of FAAs compared to the wet-aged $[8,10]$. In this study, the release of FAAs following inbag dry-ageing was more evident than that of wet-ageing, where significant $(p<0.05)$ increases were only detected in isoleucine, lysine, aspartic acid and proline (Table 7, $0 \mathrm{~min}$ ). Such changes in FAA compositions could be explained by two mechanisms: the activity of aminopeptidases due to the growth of yeast (Table 2) and a higher ageing temperature used for the in-bag dry-ageing process. The activity of aminopeptidases by yeast is known to contribute towards the release of FAAs in dry cured/fermented meat products as well [53]. On the other hand, different ageing temperatures $\left(2\right.$ vs. $\left.-1.5^{\circ} \mathrm{C}\right)$ used in the current study may also have contributed to the changes in the FAA profile between two ageing regimes. A significantly higher level of tryptophan, phenylalanine, valine, tyrosine, glutamate, isoleucine and leucine was detected in dry-aged beef at $3{ }^{\circ} \mathrm{C}$ compared to the wet-aged equivalents at $1{ }^{\circ} \mathrm{C}$ by Kim [7]. However, such a contributory effect of ageing temperature on the activity of proteases was not supported by the findings of the protein profile between the two ageing regimes in this study. Thus, there remains a need for future study to assess the actual impact of the slight increase in ageing temperature on the proteolytic pattens of in-bag dry-aged lamb. 


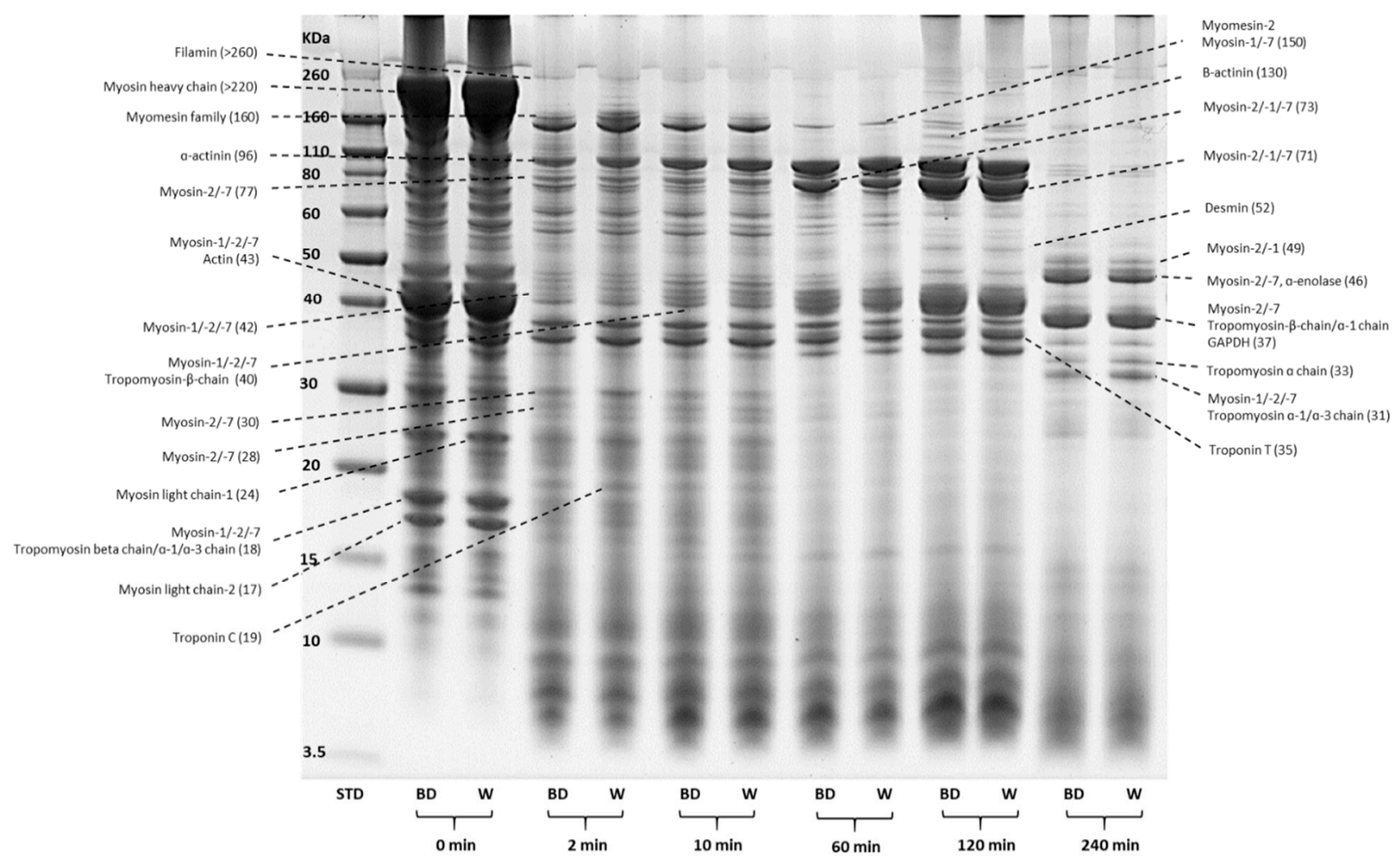

Figure 3. SDS-PAGE protein profile of in vitro gastrointestinal digestion of in-bag dry-aged (BD) and wet-aged (W) lamb chops; protein identification was according to Farouk [28] and $\mathrm{Wu}$ [54].

\subsection{In Vitro Digestibility}

In vitro protein digestibility was measured in three ways, as described by Zhang [29]: (1) by using SDS-PAGE to determine the changes in protein profiles with four hours of digestion time, simulating peptic and pancreatic digestions in the upper and lower gastrointestinal tract; (2) by measuring the changes in FAAs with the digestion simulation; and (3) by measuring the protein content in the final hydrolysate.

\subsubsection{Changes in Protein Profiles (SDS-PAGE)}

The representative SDS-PAGE protein profiles of in-bag dry- and wet-aged lamb at five sampling time points $(0,2,10,60,120$ and $240 \mathrm{~min})$ during four hours of simulated digestion process are shown in Figure 3 . The $\%$ relative quantity $[(\% R Q=$ optical density of the protein fragments/optical density of total proteins) $\times 100 \%$ ] was used to compare the quantitative differences of protein fragments between the ageing treatments. Protein fragments of different MW were grouped into seven MW groups (>110, 60-110, 50-60, $40-50,30-40,20-30$ and $<20 \mathrm{kDa}$ ) for statistical analysis, as shown in Figure 4 . There was no significant $(p>0.05)$ difference in the \% RQ of the seven MW groups between in-bag dry- and wet-aged lamb over the digestion period (data not shown). Therefore, statistical analysis of these protein groups was performed on the average $\%$ RQ of the two ageing treatments.

Most of the large-sized proteins, including filamin, titin and nebulin ( $>250 \mathrm{kDa})$ and myosin heavy chain (MHC, $>220 \mathrm{kDa}$ ), were digested rapidly by pepsin and the protein bands disappeared within $10 \mathrm{~min}$ of pepsin digestion (Figure 3) [28,54]. Myomesin and myosin family proteins of MW of 150-160 kDa were progressively cleaved through the gastric digestion with accumulation of lower MW (60-110 kDa) protein fragments. This was also seen with the $\%$ RQ results, where large MW proteins (>110 KDa) were significantly $(p<0.05)$ reduced over the gastric digestion process with significantly $(p<0.05)$ increased protein fragments of MW between 60 and $110 \mathrm{kDa}$ (Figure 4). 
Table 7. Effect of ageing treatments on the release of free amino acids ( $\mathrm{mg} / \mathrm{g}$ protein) of lamb chops at different digestion stages of the in vitro digestion process.

\begin{tabular}{|c|c|c|c|c|c|c|c|c|c|c|c|c|c|c|c|c|c|c|c|c|}
\hline & \multicolumn{3}{|c|}{$0 \mathrm{Min}$} & \multicolumn{3}{|c|}{2 Min } & \multicolumn{3}{|c|}{$10 \mathrm{~min}$} & \multicolumn{3}{|c|}{$60 \mathrm{Min}$} & \multicolumn{3}{|c|}{120 Min } & \multicolumn{3}{|c|}{240 Min } & \multirow{2}{*}{ SED $^{2}$} & \multirow{2}{*}{$\begin{array}{c}p \text {-Ageing } \\
\text { (Across Digestion Time) }\end{array}$} \\
\hline & $\mathrm{W}^{1}$ & BD $^{1}$ & $p$-Ageing & W & BD & $p$-Ageing & W & BD & $p$-Ageing & W & BD & $p$-Ageing & W & BD & $p$-Ageing & W & BD & $p$-Ageing & & \\
\hline \multicolumn{21}{|c|}{ Essential amino acids } \\
\hline Histidine & 0.36 & 0.46 & 0.252 & 0.35 & 0.41 & 0.202 & 0.37 & 0.40 & 0.481 & $0.42^{\mathrm{a}}$ & $0.60^{\mathrm{b}}$ & 0.021 & $0.38^{\mathrm{a}}$ & $0.57^{\mathrm{b}}$ & 0.001 & $0.73^{\mathrm{a}}$ & $0.87^{\mathrm{b}}$ & 0.034 & 0.06 & $<0.0001$ \\
\hline Isoleucine & $1.24^{\mathrm{a}}$ & $1.57^{\mathrm{b}}$ & 0.018 & 0.87 & 0.94 & 0.570 & 0.87 & 0.92 & 0.458 & $0.97^{\mathrm{a}}$ & $1.21^{\mathrm{b}}$ & 0.049 & $1.00^{\mathrm{a}}$ & $1.31^{\mathrm{b}}$ & 0.005 & 1.80 & 2.01 & 0.153 & 0.10 & $<0.0001$ \\
\hline Leucine & 1.01 & 0.98 & 0.907 & 1.49 & 1.60 & 0.574 & 1.51 & 1.59 & 0.507 & 1.77 & 2.18 & 0.075 & $1.89^{\mathrm{a}}$ & $2.49^{\mathrm{b}}$ & 0.005 & 12.13 & 12.75 & 0.591 & 0.50 & 0.150 \\
\hline Lysine & $1.01^{\mathrm{a}}$ & $1.19^{\mathrm{b}}$ & 0.001 & 1.27 & 1.39 & 0.528 & 1.46 & 1.59 & 0.463 & $1.42^{\mathrm{a}}$ & $2.01^{b}$ & 0.021 & $1.37^{\mathrm{a}}$ & $2.10^{\mathrm{b}}$ & 0.002 & 13.56 & 13.36 & 0.922 & 0.88 & 0.505 \\
\hline Methionine & 0.66 & 0.72 & 0.491 & 0.66 & 0.71 & 0.571 & 0.59 & 0.59 & 0.996 & 0.73 & 0.82 & 0.410 & 0.79 a & $0.97^{b}$ & 0.030 & 1.89 & 2.05 & 0.438 & 0.11 & 0.063 \\
\hline Phenylalanine & 1.60 & 2.00 & 0.144 & 1.00 & 1.03 & 0.669 & 0.99 & 1.01 & 0.632 & 1.25 & 1.38 & 0.180 & $1.46^{\mathrm{a}}$ & $1.70^{\mathrm{b}}$ & 0.025 & 10.41 & 10.91 & 0.632 & 0.44 & 0.218 \\
\hline Threonine & 1.34 & 1.73 & 0.153 & 0.56 & 0.63 & 0.285 & 0.63 & 0.77 & 0.305 & $0.67^{\mathrm{a}}$ & $0.98^{\mathrm{b}}$ & 0.045 & $0.65^{\mathrm{a}}$ & $1.01^{b}$ & 0.007 & $0.82^{\mathrm{a}}$ & $1.05^{\mathrm{b}}$ & 0.004 & 0.14 & $<0.0001$ \\
\hline Tryptophan & 0.24 & 0.30 & 0.238 & 0.53 & 0.55 & 0.424 & 0.55 & 0.56 & 0.704 & 0.63 & 0.68 & 0.125 & $0.67^{\mathrm{a}}$ & $0.75^{b}$ & 0.011 & 2.55 & 2.58 & 0.898 & 0.11 & 0.372 \\
\hline \multicolumn{21}{|c|}{ Non-essential amino acids } \\
\hline Alanine & 1.97 & 2.21 & 0.547 & 3.25 & 3.57 & 0.405 & 3.38 & 3.51 & 0.771 & 3.78 & 4.36 & 0.242 & $3.92^{\mathrm{a}}$ & $4.93^{b}$ & 0.034 & 3.91 & 4.60 & 0.101 & 0.39 & 0.004 \\
\hline Arginine & 1.35 & 1.63 & 0.152 & 1.04 & 1.16 & 0.380 & 1.02 & 1.08 & 0.599 & $1.25^{\mathrm{a}}$ & $1.49^{\mathrm{b}}$ & 0.034 & 1.40 & 1.64 & 0.155 & 20.02 & 20.12 & 0.963 & 0.91 & 0.643 \\
\hline Asparagine & 0.45 & 0.59 & 0.124 & 0.46 & 0.53 & 0.227 & 0.52 & 0.55 & 0.585 & 0.82 & 0.82 & 0.768 & $1.24^{\mathrm{a}}$ & $1.73^{\mathrm{a}}$ & 0.004 & $1.46^{\mathrm{a}}$ & $1.84^{\mathrm{b}}$ & 0.008 & 0.11 & $<0.0001$ \\
\hline Aspartic acid & $0.35^{\mathrm{a}}$ & $0.64^{\mathrm{b}}$ & 0.043 & 0.49 & 0.52 & 0.688 & 0.70 & 0.76 & 0.446 & $0.60^{a}$ & $1.00^{\mathrm{b}}$ & 0.004 & $0.63^{\mathrm{a}}$ & $1.15^{\mathrm{b}}$ & 0.000 & $0.67^{a}$ & $1.11^{\mathrm{b}}$ & 0.000 & 0.09 & $<0.0001$ \\
\hline Cysteine & 0.04 & 0.04 & 0.236 & $0.69^{a}$ & $0.83^{b}$ & 0.014 & 0.85 & 0.98 & 0.412 & $0.91^{\mathrm{a}}$ & $1.19^{\mathrm{b}}$ & 0.046 & $0.91^{\mathrm{a}}$ & $1.30^{\mathrm{b}}$ & 0.002 & 1.18 & 1.38 & 0.233 & 0.11 & $<0.0001$ \\
\hline Glutamic acid & 0.93 & 1.16 & 0.354 & 1.13 & 1.24 & 0.534 & 1.25 & 1.17 & 0.630 & 1.36 & 1.59 & 0.139 & $1.47^{\mathrm{a}}$ & $1.81^{\mathrm{b}}$ & 0.007 & $1.36^{\mathrm{a}}$ & $1.69^{\mathrm{b}}$ & 0.044 & 0.16 & 0.005 \\
\hline Glutamine & 3.67 & 4.18 & 0.447 & 2.97 & 3.26 & 0.567 & 2.94 & 3.22 & 0.672 & 3.68 & 4.14 & 0.367 & 3.43 & 4.58 & 0.056 & 3.68 & 4.50 & 0.258 & 0.59 & 0.017 \\
\hline Glycine & 1.19 & 1.28 & 0.603 & 2.80 & 2.92 & 0.659 & 2.71 & 2.91 & 0.254 & 2.94 & 3.19 & 0.232 & $2.92^{\mathrm{a}}$ & $3.50^{\mathrm{b}}$ & 0.008 & 3.29 & 3.78 & 0.054 & 0.20 & 0.001 \\
\hline Hydroxyproline & 0.11 & 0.11 & 0.847 & 0.04 & 0.05 & 0.302 & 0.04 & 0.04 & 0.580 & 0.06 & 0.05 & 0.218 & 0.05 & 0.06 & 0.094 & 0.05 & 0.06 & 0.067 & 0.01 & 0.051 \\
\hline Proline & $0.50^{\mathrm{a}}$ & $0.71^{b}$ & 0.045 & 0.42 & 0.45 & 0.534 & 0.47 & 0.51 & 0.468 & $0.50^{\mathrm{a}}$ & $0.65^{b}$ & 0.031 & $0.60^{\mathrm{a}}$ & $0.85^{b}$ & 0.007 & $0.50^{\mathrm{a}}$ & $0.67^{b}$ & 0.014 & 0.06 & $<0.0001$ \\
\hline Tyrosine & 0.93 & 1.13 & 0.361 & 0.93 & 0.99 & 0.603 & 0.93 & 0.98 & 0.384 & 1.11 & 1.29 & 0.129 & $1.15^{\mathrm{a}}$ & $1.43^{b}$ & 0.008 & 8.63 & 9.01 & 0.657 & 0.37 & 0.203 \\
\hline $\mathrm{EAAs}^{3}$ & 8.48 & 10.23 & 0.092 & 7.88 & 8.52 & 0.498 & 8.20 & 8.72 & 0.460 & 9.23 & 11.56 & 0.044 & 9.56 & 12.75 & 0.005 & 45.81 & 47.92 & 0.682 & 2.24 & 0.063 \\
\hline$\%$ EAAs & 40.43 & 40.65 & 0.895 & 33.53 & 33.39 & 0.874 & 33.56 & 33.73 & 0.877 & 33.46 & 34.55 & 0.484 & 32.98 & 33.57 & 0.569 & 49.51 & 48.53 & 0.258 & 1.15 & 0.790 \\
\hline Total AAs ${ }^{3}$ & 21.17 & 25.36 & 0.211 & 23.48 & 25.54 & 0.458 & 24.51 & 25.99 & 0.547 & 27.82 & 33.37 & 0.052 & $28.99^{a}$ & $37.96^{\mathrm{b}}$ & 0.003 & 92.25 & 98.84 & 0.499 & 4.59 & 0.014 \\
\hline
\end{tabular}

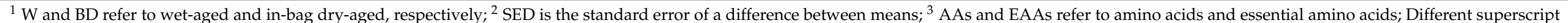
letters " $\mathrm{a}$, $\mathrm{b}$ " within the same row indicate that results significantly differed from each other $(p<0.05)$. 


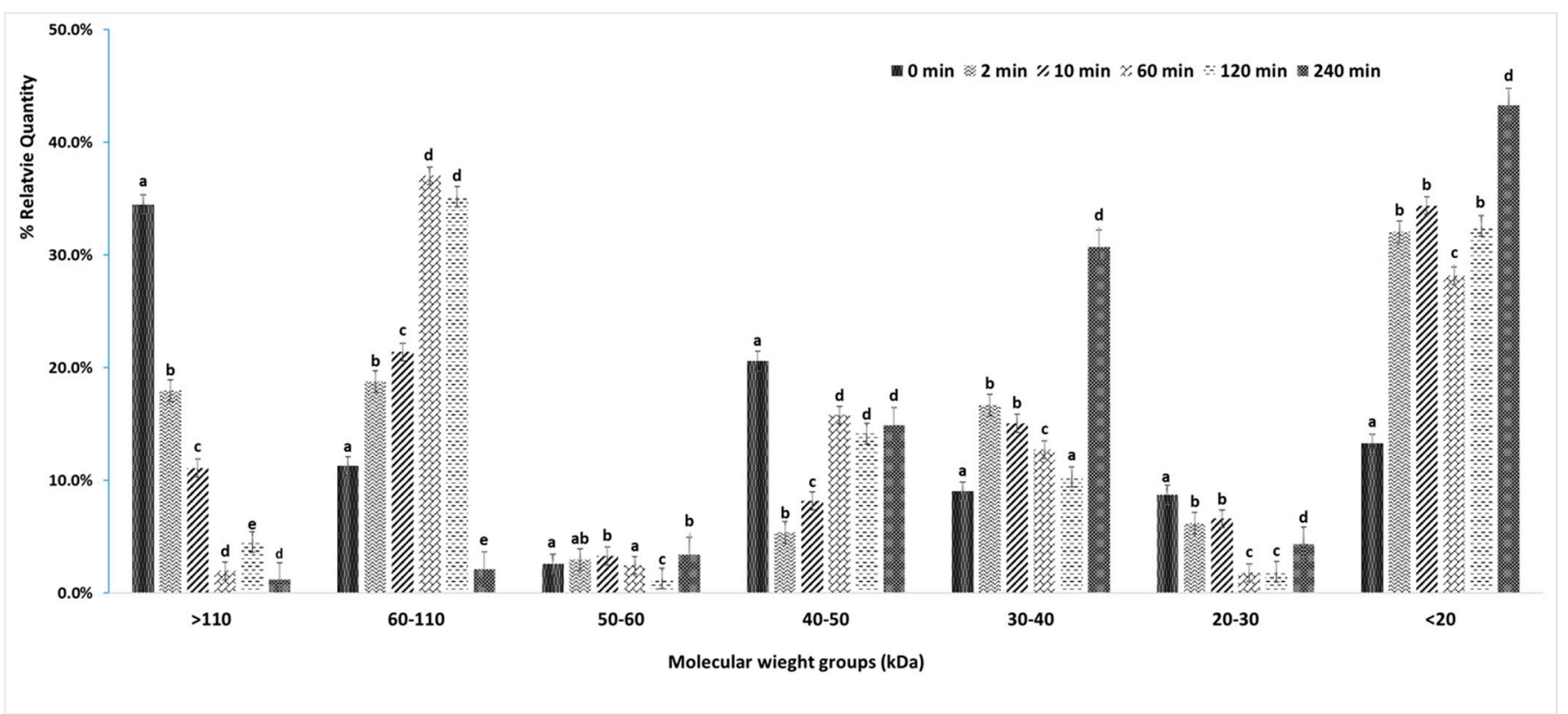

Figure 4. Relative quantity changes (mean \pm standard error) of seven major molecular weight protein groups across the gastrointestinal digestion process $(0,2,10,60,120$ and $240 \mathrm{~min}$.). The relative quantity of protein fragments significantly differed across the digestion process when means showed different letters " $a, b, c, d, e$ " within the same molecular weight group $(p<0.05)$.

Protein fragments of MW 50-60 kDa were quickly digested within the first 2 min of gastric digestion, with continuous cleavage throughout the digestion period (Figure 3). Another group of protein fragments with significant changes in protein profiles ranged from 30 to $50 \mathrm{kDa}$, which mainly consisted of myosin family, actin and tropomyosin family $[28,54]$. These protein fragments underwent rapid partial digestion by pepsin at the initial stage $(2 \mathrm{~min})$. The broken fragments became resistant to pepsin and accumulated throughout the gastric digestion, as evidenced by the significant decrease in the $\%$ RQ of proteins $(40-50 \mathrm{kDa}$ ) within the first $10 \mathrm{~min}$, with no further changes afterward (Figure 4). The low MW protein fragments (10-30 kDa) included myosin- $1,-2$ and -7 , myosin light chain- 1 and -2 , Troponin C, which were readily digested within 60 min of gastric digestion. The \% RQ of low MW proteins (20-30 kDa) significantly reduced over the gastric digestion, while the smaller protein fragments $(<20 \mathrm{kDa})$ increased significantly $(p<0.05)$ within 2 min and then varied slightly throughout the pepsin digestion time of $120 \mathrm{~min}$.

The protein fragments that resisted gastric digestions $(30-50 \mathrm{kDa})$ were further hydrolysed to smaller fragments during the subsequent $120 \mathrm{~min}$ of pancreatic digestion (Figure 3). These fragments may include proline-containing peptides that are reported to resist digestion by pancreatic enzymes [55]. This is further supported by the relatively unchanged amount of proline in the hydrolysates over the digestion simulation period (Table 7). Farouk [28] also observed the resistance of these protein fragments to pancreatic digestion in beef samples. The \% RQ of proteins above $60 \mathrm{kDa}$ significantly decreased $(p<0.05)$ at the end of pancreatic digestion $(240 \mathrm{~min})$, with a significant $(p<0.05)$ increase in the \% RQs of 30-40 $\mathrm{kDa}$ proteins.

\subsubsection{Changes in FAAs}

The release of FAAs over the four hours of gastrointestinal digestion is shown in Table 7. The FAA level increased to around three times by the end of pancreatic digestion (240 $\mathrm{min}$ ) compared to the gastric phase levels $(120 \mathrm{~min})$. The percentage of EAAs in the total AAs (\% EAAs) decreased in the first 2 min of digestion, then remained unchanged 
throughout the gastric digestion process. However, the increase in \% EAA was observed at the end of the gastrointestinal digestion simulation. Current findings indicated that the main role of gastric enzymes (pepsin) was to break down large proteins into smaller fragments ready for more complete digestion by pancreatic enzymes and the concomitant release of FAAs. Pepsin is an endopeptidase which plays a role in the cleavage of peptide bonds within molecules in the P1 and P1' positions and break down large protein molecules into smaller peptides. The pancreatic enzymes, including endopeptidases (trypsin, chymotrypsin and elastase), exopeptidases (carboxypeptidase A and B) and other proteases, are the major sources of proteases in the human digestive system. It is well known that pancreatic enzymes contribute more (around 40\%) than pepsin (10-20\%) to proteolysis during human gastrointestinal digestion [56].

A significant increase in EAAs at the end of digestion was observed. These consisted of leucine, lysine, phenylalanine, tyrosine and arginine, as previously observed in drycured ovine meat [22]. This can be explained by the selective cleavage of peptide bonds, which link the carboxyl side of basic AAs (e.g., lysine and arginine) by trypsin [56], and the preferential cleavage of the linkage between aromatic AAs (e.g., phenylalanine and tyrosine) by chymotrypsin [55]. Elastase is another pancreatic endopeptidase responsible for the cleavage of the carboxyl side of aliphatic AAs, which includes alanine, glycine, isoleucine, leucine and valine [55]. The exposure of these AAs can act as substrates to be further digested by exopeptidases (Carboxypeptidase A and B), which may explain the significant increase in these AAs after 120 min of pancreatic digestion observed in the current study (Table 7).

There was no significant difference between the ageing treatments within the first 10 min of gastric digestion, except for a significantly $(p<0.05)$ higher content of cysteine in dry-aged lamb. With time, EAAs including isoleucine, lysine, threonine and valine, and non-essential AAs (non-EAAs) comprising arginine, aspartic acid, cysteine, histidine and proline, significantly increased in dry-aged lamb compared to the wet-aged equivalents (Table 7,60 min, $p<0.05$ ). A significant difference in FAAs observed between ageing treatments at $120 \mathrm{~min}$ of gastric digestion was not observed following the $120 \mathrm{~min}$ of pancreatic digestion $(p>0.05)$, probably due to the greater cleavage of protein fragments by pancreatic enzymes that resulted in similar levels of FAAs being released in both ageing treatments.

When considering the FAA level between ageing treatments across the digestion process, three EAAs (isoleucine, threonine and valine) and most of the non-EAAs (except for hydroxyproline and arginine) were significantly $(p<0.05)$ higher in dry-aged lamb as compared to the wet-aged control. Therefore, based on the release of FAAs during gastric digestion, dry-aged lamb was more digestible than the wet-aged equivalent. The higher digestibility of dry-aged lamb products could also be attributed to the significantly $(p<0.05)$ higher yeast counts in the dry-aged sample compared to the control (Table 2). The presence of yeast in meat products has been associated with an increase in $\mathrm{pH}$ and the production of peptides, free fatty acids, FAAs and flavour compounds $[52,57,58]$. Thus, it is our assumption that a mild fermentation induced by yeast may have occurred during the dry-ageing process that could have contributed to the higher FAAs and smaller peptides in dry-aged lamb. Further studies are required to isolate and identify the yeast strain and to determine its role in the improvement of proteolysis and digestibility.

\subsubsection{Protein Content in Hydrolysate}

The protein content (protein fragments and peptides) in the final hydrolysates following 240-min simulated digestion was determined and no significant difference $(p>0.05)$ between the two ageing treatments was found (data not shown). Only $70 \%$ of the proteins were hydrolysed, with around $30 \%$ of protein hydrolysates remaining in the digests. This could be explained by the limitation of pancreatic proteases, which accounts for only $30-40 \%$ of protein hydrolysis occurring in human gastrointestinal digestion $[55,59]$. 


\subsubsection{Overall Relative Protein Digestibility (\%)}

The relative protein digestibility of dry-aged lamb products compared to the wet-aged control was determined by three methods. As shown in Table 8, both ageing regimes had similar digestibility regardless of the method used. Although the overall relative protein digestibility did not differ when the full $240 \mathrm{~min}$ of gastric and pancreatic digestions were considered together, it is important to note that from the analysis of the FAAs, we were able to determine that dry-aged meat had a higher gastric digestibility compared to wet-aged. This information is particularly relevant because the increased digestibility of meat at the upper gastrointestinal tract will minimise the chances of larger fragments of proteins reaching the lower gastrointestinal tract, where they may be fermented to produce metabolites that could contribute to bowel ailments in the elderly and those with compromised guts $[60,61]$. Thus, we recommend that a combination of assessment methods - such as the three used in the current study-be employed in order to fully determine the extent of the digestibility of meat.

Table 8. Overall relative digestibility (\%) of lamb chops following 240-min in vitro digestion.

\begin{tabular}{ccccc}
\hline & $\mathbf{W}^{\mathbf{1}}$ & BD $^{\mathbf{1}}$ & $\boldsymbol{p}^{- \text {Ageing }}$ & SED $^{\mathbf{2}}$ \\
\hline Relative digestibility SDS-PAGE & 63.96 & 65.24 & 0.776 & 4.36 \\
Relative digestibility FAAs & 7.11 & 7.35 & 0.802 & 0.92 \\
Relative digestibility protein content & 70.18 & 70.75 & 0.570 & 0.95 \\
\hline
\end{tabular}

${ }^{1} \mathrm{~W}$ and BD refer to wet-aged and in-bag dry-aged, respectively; ${ }^{2}$ SED is the standard error of a difference between means.

\section{Conclusions}

This is the first time that in-bag dry-aged lamb was produced and a systematic study was performed to compare the product with its wet-aged equivalents in terms of meat quality, consumer acceptability, oxidative stability and digestibility considerations. The current findings demonstrated that the in-bag dry-ageing process can be used to produce highly acceptable lamb products with comparable meat quality and oxidative stability and with improved gastric digestibility compared to the wet-aged equivalents. Future studies focusing on determining the role of yeast in proteolysis during dry-ageing, and the improvement of gastric digestibility, will further validate the current findings.

The outcomes also confirmed the niche nature of dry-aged meat compared to the equivalent wet-aged lamb and provided a formula for determining the yield of dry-aged lamb legs from its initial wet weight.

A combination of SDS-PAGE, FAA and total protein measurement of digests enabled better assessment of meat digestibility than the use of each method alone. The use of FAA profiling in conjunction with SDS-PAGE will help us to better understand the biochemical processes during the digestion of meat products, particularly in the upper gastrointestinal tract, which is important when the bioaccessibility of the products is of interest.

Author Contributions: Conceptualization, R.Z. and M.M.F.; methodology, R.Z.; software, R.Z.; validation, R.Z.; formal analysis, R.Z. and M.S.; investigation, R.Z.; resources, M.M.F.; data curation, R.Z. and M.S.; writing—original draft preparation, R.Z.; writing—review and editing, R.Z., M.J.Y.Y., C.E.R., M.S. and M.M.F.; visualization, R.Z.; supervision, M.J.Y.Y. and M.M.F.; project administration, R.Z.; funding acquisition, M.M.F. and M.J.Y.Y. All authors have read and agreed to the published version of the manuscript.

Funding: This research was supported by Ministry of Science and Innovation, New Zealand, and from the internal Strategic Science Investment Fund of AgResearch Limited (contract A19113).

Institutional Review Board Statement: The consumer sensory study was approved by Ethics Committee of Auckland University of Technology (protocol code 17/78 and 14 December 2018).

Informed Consent Statement: Informed consent was obtained from all subjects involved in the study. 
Data Availability Statement: The data presented in this study are available on request from the corresponding author.

Acknowledgments: The first author would like to acknowledge Auckland University of Technology for his PhD scholarship from the Performance Based Research Fund. The authors would like to acknowledge Kevin Taukiri and Debbie A. Frost for assistance with the collection of samples, Bruce Small and Cameron Craigie for assistance with sensory testing and Harold Henderson for statistical advice.

Conflicts of Interest: The authors declare no conflict of interest.

\section{References}

1. Li, X.; Babol, J.; Bredie, W.L.P.; Nielsen, B.; Tománková, J.; Lundström, K. A comparative study of beef quality after ageing longissimus muscle using a dry ageing bag, traditional dry ageing or vacuum package ageing. Meat Sci. 2014, 97, 433-442. [CrossRef]

2. Savell, J.W. Dry-Aging of Beef: Executive Summary; Center for Research and Knowledge Management, National Cattlemen's Beef Association: Texas, Estados Unidos, 2008.

3. Ahnström, M.L.; Seyfert, M.; Hunt, M.C.; Johnson, D.E. Dry aging of beef in a bag highly permeable to water vapour. Meat Sci. 2006, 73, 674-679. [CrossRef]

4. Kim, Y.H.B.; Ma, D.; Setyabrata, D.; Farouk, M.M.; Lonergan, S.M.; Huff-Lonergan, E.; Hunt, M.C. Understanding postmortem biochemical processes and post-harvest aging factors to develop novel smart-aging strategies. Meat Sci. 2018, 144, 74-90. [CrossRef]

5. Zhang, R.; Yoo, M.J.; Farouk, M. Quality and acceptability of fresh and long-term frozen in-bag dry-aged lean bull beef. J. Food Qual. 2019, 2019, 1-15. [CrossRef]

6. Benatti, P.; Peluso, G.; Nicolai, R.; Calvani, M. Polyunsaturated fatty acids: Biochemical, nutritional and epigenetic properties. J. Am. Coll. Nutr. 2004, 23, 281-302. [CrossRef] [PubMed]

7. Kim, Y.H.B.; Kemp, R.; Samuelsson, L.M. Effects of dry-aging on meat quality attributes and metabolite profiles of beef loins. Meat Sci. 2016, 111, 168-176. [CrossRef] [PubMed]

8. Lee, H.J.; Choe, J.; Kim, M.; Kim, H.C.; Yoon, J.W.; Oh, S.W.; Jo, C. Role of moisture evaporation in the taste attributes of dry- and wet-aged beef determined by chemical and electronic tongue analyses. Meat Sci. 2019, 151, 82-88. [CrossRef]

9. Oh, H.; Lee, H.J.; Lee, J.; Jo, C.; Yoon, Y. Identification of Microorganisms Associated with the Quality Improvement of Dry-Aged Beef Through Microbiome Analysis and DNA Sequencing, and Evaluation of Their Effects on Beef Quality. J. Food Sci. 2019, 84, 2944-2954. [CrossRef]

10. Lee, H.J.; Yoon, J.W.; Kim, M.; Oh, H.; Yoon, Y.; Jo, C. Changes in microbial composition on the crust by different air flow velocities and their effect on sensory properties of dry-aged beef. Meat Sci. 2019, 153, 152-158. [CrossRef]

11. Martinaud, A.; Mercier, Y.; Marinova, P.; Tassy, C.; Gatellier, P.; Renerre, M. Comparison of oxidative processes on myofibrillar proteins from beef during maturation and by different model oxidation systems. J. Agric. Food Chem. 1997, 45, $2481-2487$. [CrossRef]

12. Park, D.; Xiong, Y.L.; Alderton, A.A.L.; Ooizumi, T. Biochemical changes in myofibrillar protein isolates exposed to three oxidizing systems. J. Agric. Food Chem. 2006, 54, 4445-4451. [CrossRef] [PubMed]

13. Santé-Lhoutellier, V.; Engel, E.; Aubry, L.; Gatellier, P. Effect of animal (lamb) diet and meat storage on myofibrillar protein oxidation and in vitro digestibility. Meat Sci. 2008, 79, 777-783. [CrossRef] [PubMed]

14. Lund, M.N.; Heinonen, M.; Baron, C.P.; Estévez, M. Protein oxidation in muscle foods: A review. Mol. Nutr. Food Res. 2010, 55, 83-95. [CrossRef] [PubMed]

15. Berardo, A.; Claeys, E.; Vossen, E.; Leroy, F.; De Smet, S. Protein oxidation affects proteolysis in a meat model system. Meat Sci. 2015, 106, 78-84. [CrossRef] [PubMed]

16. Sante-Lhoutellier, V.; Aubry, L.; Gatellier, P. Effect of oxidation on in vitro digestibility of skeletal muscle myofibrillar proteins. J. Agric. Food Chem. 2007, 55, 5343-5348. [CrossRef] [PubMed]

17. Domínguez, R.; Pateiro, M.; Gagaoua, M.; Barba, F.J.; Zhang, W.; Lorenzo, J.M. A Comprehensive review on lipid oxidation in meat and meat products. Antioxidants 2019, 8, 429. [CrossRef]

18. Resconi, V.C.; Bueno, M.; Escudero, A.; Magalhaes, D.; Ferreira, V.; Campo, M.M. Ageing and retail display time in raw beef odour according to the degree of lipid oxidation. Food Chem. 2018, 242, 288-300. [CrossRef]

19. Li, X.; Babol, J.; Wallby, A.; Lundström, K. Meat quality, microbiological status and consumer preference of beef gluteus medius aged in a dry ageing bag or vacuum. Meat Sci. 2013, 95, 229-234. [CrossRef]

20. AOAC. Official Methods of Analysis, 18th ed.; Association of Official Analytical Chemists: Washington, DC, USA, 2010.

21. Downes, F.P.; Ito, K. Compendium of Methods Microbiological Examination of Foods, 4th ed.; American Public Health Association: Washington, DC, USA, 2001.

22. Zhang, R.; Yoo, M.J.; Gathercole, J.; Reis, M.G.; Farouk, M.M. Effect of animal age on the nutritional and physicochemical qualities of ovine bresaola. Food Chem. 2018, 254, 317-325. [CrossRef]

23. McLafferty, I. Focus group interviews as a data collecting strategy. J. Adv. Nurs. 2004, 48, 187-194. [CrossRef] 
24. Powell, R.A.; Single, H.M. Focus groups. Int. J. Qual. Health Care 1996, 8, 499-504. [CrossRef] [PubMed]

25. Rabiee, F. Focus-group interview and data analysis. Proc. Nutr. Soc. 2004, 63, 655-660. [CrossRef]

26. Levine, R.L.; Garland, D.; Oliver, C.N.; Amici, A.; Climent, I.; Lenz, A.-G.; Ahn, B.-W.; Shaltiel, S.; Stadtman, E.R. Determination of carbonyl content in oxidatively modified proteins. Methods in Enzymology 1990, 186, 464-478. [CrossRef]

27. Buege, J.A.; Aust, S.D. Microsomal lipid peroxidation. Methods Enzymol. 1978, 52, 302-310. [PubMed]

28. Farouk, M.; Wu, G.; Frost, D.A.; Clerens, S.; Knowles, S.O. The in vitro digestibility of beef varies with its inherent ultimate pH. Food Funct. 2014, 5, 2759-2767. [CrossRef] [PubMed]

29. Zhang, R.; Yoo, M.J.; Farouk, M.M. Oxidative stability, proteolysis, and in vitro digestibility of fresh and long-term frozen stored in-bag dry-aged lean beef. Food Chem. 2020, 128601. [CrossRef] [PubMed]

30. DeGeer, S.; Hunt, M.; Bratcher, C.; Crozier-Dodson, B.; Johnson, D.; Stika, J. Effects of dry aging of bone-in and boneless strip loins using two aging processes for two aging times. Meat Sci. 2009, 83, 768-774. [CrossRef]

31. Dikeman, M.E.; Obuz, E.; Gök, V.; Akkaya, L.; Stroda, S. Effects of dry, vacuum, and special bag aging; USDA quality grade; and end-point temperature on yields and eating quality of beef Longissimus lumborum steaks. Meat Sci. 2013, 94, 228-233. [CrossRef]

32. Kim, Y.H.B.; Meyers, B.; Kim, H.-W.; Liceaga, A.M.; LeMenager, R.P. Effects of stepwise dry/wet-aging and freezing on meat quality of beef loins. Meat Sci. 2017, 123, 57-63. [CrossRef]

33. Obuz, E.; Akkaya, L.; Gök, V.; Dikeman, M.E. Effects of blade tenderization, aging method and aging time on meat quality characteristics of Longissimus lumborum steaks from cull Holstein cows. Meat Sci. 2014, 96, 1227-1232. [CrossRef]

34. Hulankova, R.; Kameník, J.; Saláková, A.; Závodský, D.; Borilova, G. The effect of dry aging on instrumental, chemical and microbiological parameters of organic beef loin muscle. LWT 2018, 89, 559-565. [CrossRef]

35. Ponnampalam, E.N.; Hopkins, D.L.; Bruce, H.; Li, D.; Baldi, G.; Bekhit, A.E.-D.A. Causes and contributing factors to "dark cutting" meat: Current trends and future directions: A Review. Compr. Rev. Food Sci. Food Saf. 2017, 16, 400-430. [CrossRef]

36. Seideman, S.C.; Cross, H.R.; Smith, G.C.; Durland, P.R. Factors associated with fresh meat color: A review. J. Food Qual. 1984, 6, 211-237. [CrossRef]

37. Renerre, M.; Labas, R. Biochemical factors influencing metmyoglobin formation in beef muscles. Meat Sci. 1987, 19, 151-165. [CrossRef]

38. Sitz, B.M.; Calkins, C.R.; Feuz, D.M.; Umberger, W.J.; Eskridge, K.M. Consumer sensory acceptance and value of wet-aged and dry-aged beef steaks1. J. Anim. Sci. 2006, 84, 1221-1226. [CrossRef] [PubMed]

39. Stenström, H.; Li, X.; Hunt, M.C.; Lundström, K. Consumer preference and effect of correct or misleading information after ageing beef longissimus muscle using vacuum, dry ageing, or a dry ageing bag. Meat Sci. 2014, 96, 661-666. [CrossRef]

40. Berger, J.; Kim, Y.H.B.; Legako, J.F.; Martini, S.; Lee, J.; Ebner, P.; Zuelly, S.M.S. Dry-aging improves meat quality attributes of grass-fed beef loins. Meat Sci. 2018, 145, 285-291. [CrossRef] [PubMed]

41. Smith, R.D.; Nicholson, K.L.; Nicholson, J.D.W.; Harris, K.B.; Miller, R.K.; Griffin, D.B.; Savell, J.W. Dry versus wet aging of beef: Retail cutting yields and consumer palatability evaluations of steaks from US Choice and US Select short loins. Meat Sci. 2008, 79, 631-639. [CrossRef] [PubMed]

42. O'Quinn, T.; Woerner, D.; Engle, T.; Chapman, P.; Legako, J.; Brooks, J.; Belk, K.; Tatum, J. Identifying consumer preferences for specific beef flavor characteristics in relation to cattle production and postmortem processing parameters. Meat Sci. 2016, 112, 90-102. [CrossRef]

43. Wood, J. Fat deposition and the quality of fat tissue in meat animals. In Fats in Animal Nutrition; Wiseman, J., Ed.; ButterworthHeinemann: Oxford, UK, 1984; pp. 407-435.

44. Young, O.A.; Reid, D.H.; Smith, M.E.; Braggins, T.J. Sheepmeat odour and flavour. In Flavor of Meat and Meat Products; Springer Science and Business Media LLC: Berlin/Heidelberg, Germany, 1994; pp. 71-97.

45. Estévez, M. Protein carbonyls in meat systems: A review. Meat Sci. 2011, 89, 259-279. [CrossRef] [PubMed]

46. Min, B.; Ahn, D. Mechanism of lipid peroxidation in meat and meat products-A review. Food Sci. Biotechnol. 2005, 14, 152-163.

47. Campo, M.M.; Nute, G.R.; Hughes, S.I.; Enser, M.; Wood, J.D.; Richardson, R.I. Flavour perception of oxidation in beef. Meat Sci. 2006, 72, 303-311. [CrossRef] [PubMed]

48. Jiang, T.; Busboom, J.R.; Nelson, M.L.; O’Fallon, J.; Ringkob, T.P.; Rogers-Klette, K.R.; Joos, D.; Piper, K. The influence of forage diets and aging on beef palatability. Meat Sci. 2010, 86, 642-650. [CrossRef] [PubMed]

49. Khan, M.I.; Jo, C.; Tariq, M.R. Meat flavor precursors and factors influencing flavor precursors-A systematic review. Meat Sci. 2015, 110, 278-284. [CrossRef]

50. Mottram, D.S. Flavour formation in meat and meat products: A review. Food Chem. 1998, 62, 415-424. [CrossRef]

51. Watanabe, A.; Kamada, G.; Imanari, M.; Shiba, N.; Yonai, M.; Muramoto, T. Effect of aging on volatile compounds in cooked beef. Meat Sci. 2015, 107, 12-19. [CrossRef]

52. Choe, J.; Park, B.; Lee, H.J.; Jo, C. Potential antioxidant and angiotensin I-converting enzyme inhibitory activity in crust of dry-aged beef. Sci. Rep. 2020, 10, 1-8. [CrossRef]

53. Flores, M.; Toldrá, F. Microbial enzymatic activities for improved fermented meats. Trends Food Sci. Technol. 2011, 22, 81-90. [CrossRef]

54. Wu, G.; Clerens, S.; Farouk, M. LC MS/MS identification of large structural proteins from bull muscle and their degradation products during post mortem storage. Food Chem. 2014, 150, 137-144. [CrossRef] 
55. Sitrin, M.D. Digestion and absorption of carbohydrates and proteins. In The Gastrointestinal System: Gastrointestinal, Nutritional and Hepatobiliary Physiology; Leung, P.S., Ed.; Springer: Dordrecht, The Netherlands, 2014; pp. 137-158.

56. Krehbiel, C.R.; Matthews, J.C. Absorption of amino acids and peptides. In Amino Acids in Animal Nutrition, 2nd ed.; D’Mello, J.F., Ed.; CABI Publishing: Wallingford, UK, 2003; pp. 41-42.

57. Flores, M.; Corral, S.; Cano-García, L.; Salvador, A.; Belloch, C. Yeast strains as potential aroma enhancers in dry fermented sausages. Int. J. Food Microbiol. 2015, 212, 16-24. [CrossRef]

58. Flores, M.; Durá, M.-A.; Marco, A.; Toldra, E. Effect of Debaryomyces spp. on aroma formation and sensory quality of dry-fermented sausages. Meat Sci. 2004, 68, 439-446. [CrossRef] [PubMed]

59. Fricker, G.; Drewe, J. Current concepts in intestinal peptide absorption. J. Pept. Sci. 1996, 2, 195-211. [CrossRef] [PubMed]

60. Corpet, D.E.; Yin, Y.; Zhang, X.; Rémésy, C.; Stamp, D.; Medline, A.; Thompson, L.; Bruce, W.R.; Archer, M.C. Colonic protein fermentation and promotion of colon carcinogenesis by thermolyzed casein. Nutr. Cancer 1995, 23, 271-281. [CrossRef] [PubMed]

61. Silvester, K.R.; Cummings, J.H. Does digestibility of meat protein help explain large bowel cancer risk? Nutr. Cancer 1995, 24, 279-288. [CrossRef] [PubMed] 